\title{
Critical factors influencing in vitro propagation and modulation of important secondary metabolites in Withania somnifera (L.) dunal
}

\author{
Kuldeep Kaur $^{1} \cdot$ Dechen Dolker $^{1} \cdot$ Shashikanta Behera ${ }^{1} \cdot$ Pratap Kumar Pati $^{1}$
}

Received: 12 August 2021 / Accepted: 29 December 2021 / Published online: 12 January 2022

(c) The Author(s), under exclusive licence to Springer Nature B.V. 2022

\begin{abstract}
Withania somnifera (L.) Dunal is a valuable medicinal plant in the Solanaceae family. It is commonly known as Ashwagandha and is widely distributed around the globe. It has multiple pharmacological properties owing to the existence of diverse secondary metabolites viz., withanolide $\mathrm{A}$, withanolide $\mathrm{D}$, withaferin $\mathrm{A}$, and withanone. It is in great demand in the herbal industry because of its extensive use. In this background, the major challenge lies in the rapid multiplication of elite cultivars of $W$. somnifera in order to produce genetically and phytoconstituents uniform plant material for pharmaceutical industries. Thus it is necessary to explore various biotechnological approaches for the clonal mass propagation and synthesis of pharmaceutically important constituents in W. somnifera. Though there are several studies on in vitro propagation on $W$. somnifera, yet many factors that critically influence the in vitro response and withanolides production need to be fine-tuned in the pretext of the existing knowledge. The current review focuses on the advancements and prospects in biotechnological interventions to meet the worldwide demands for $W$. somnifera and its bioactive compounds. This update on in vitro studies on W. somnifera will be useful to many researchers, entrepreneurs, and herbal industries looking for its in vitro mass multiplication and scientific utilization.
\end{abstract}

\section{Key message}

Withania somnifera is a high value medicinal plant. The present review discusses the advancements in in vitro propagation and important secondary metabolites biosynthesis of $W$. somnifera.

Keywords Elicitation · In vitro propagation · Meta-Topolin · Cell, Tissue and Organ culture · Withania somnifera . Withanolides

$\begin{array}{ll}\begin{array}{ll}\text { Abbreviations } \\ 1 / 2 M S\end{array} & \begin{array}{l}\text { Half-strength Murashige and Skoog (1962) } \\ \text { medium }\end{array} \\ 2,4-D & \text { 2,4-Dichlorophenoxyacetic acid } \\ B 5 & \text { Gamborg's B5 medium } \\ B A P & \text { 6-Benzylaminopurine } \\ I A A & \text { Indole-3-acetic acid } \\ I B A & \text { Indole-3-butyric acid } \\ G A_{3} & \text { Gibberellic acid } \\ K N & \text { Kinetin } \\ M S & \text { Murashige and Skoog (1962) medium }\end{array}$

Communicated by Amita Bhattacharya.

Pratap Kumar Pati

pkpati@yahoo.com

1 Department of Biotechnology, Guru Nanak Dev University, Amritsar 143005, Punjab, India

$\begin{array}{ll}m T & \text { Meta-Topolin } \\ N A A & \alpha \text {-Naphthalene acetic acid } \\ P G R s & \text { Plant growth regulators } \\ P P & \text { Photoperiod } \\ R H & \text { Relative humidity } \\ \mathrm{TDZ} & \text { Thidiazuron } \\ \mathrm{ZnSO}_{4} & \text { Zinc sulphate }\end{array}$

\section{Introduction}

The use of plants as a source of medicine has been depicted in our ancient literature (Dar et al. 2017). There has recently been a resurgence of interest in the usage of therapeutic plants and their secondary metabolites due to their easy availability, low cost, good efficacy, and minimum side effects (Jamshidi-Kia et al. 2018). In addition, more and more experimental evidence gathered on their precise role 
and mode of action against different diseases has lead to their increased acceptability and popularization. According to WHO, It is reported that $80 \%$ of the world's population depends on herbal medicine to treat a variety of health problems (Gupta et al. 2020; Uritu et al. 2018). The trade of medicinal and aromatic plants (MAP) in India is valued at around US\$ 238 million, with an annual growth rate of $8 \%$ to $10 \%$, while the global market is worth approximately US\$ 2.96 billion with a $15-25 \%$ annual growth rate (Chandra and Sharma 2019). Further, it is expected that the international trade of herbal products to grow up to $\$ 7$ trillion by 2050 (Kaur et al. 2021b). The global shift to plant-based medicines, their extraordinary demands, and the associated trades provides an enormous future opportunity to develop strategies for their mass cultivation.

Among medicinal plants, Withania somnifera occupies a distinct position owing to its immense medicinal properties including anti-cancer, cardioprotective, anti-inflammatory, immunomodulatory, anti-coagulant, anti-diabetic, anti-oxidant, and neuroprotective (Kaur et al. 2021a; Sangwan and Sangwan 2014). In silico studies on W. somnifera revealed its potential against COVID-19 by inhibiting the cell surface receptor protein (TMPRSS2) and viral protein $\left(\mathrm{M}^{\text {pro }}\right)$ of SARS-CoV-2 (Dhanjal et al. 2021). The potent therapeutic potential of this plant is mainly due to the existence of different bioactive compounds including alkaloids, steroidal lactones, glycowithanolides, sterols, flavonoids, and phenolics (Chaurasiya et al. 2012). Among these, steroidal lactones viz., withanolide A, withanolide $\mathrm{D}$, withanolide $\mathrm{E}-\mathrm{M}$, withaferin $\mathrm{A}$, and withanone have attracted the attention of researchers due to their wide range of pharmacological properties (Namdeo and Ingawale 2020; Sivanandhan et al. 2020). These secondary metabolites are differentially distributed in various parts of $W$. somnifera like leaves, fruits, and roots (Namdeo et al. 2011). Withanone and withaferin A were detected in leaves, while withanolide A, sitoindoside VIII, and sitoindoside VIII were found in roots (Karthikeyan et al. 2019; Singh et al. 2015). Further, MS and NMR spectroscopy studies on fruits of $W$. somnifera identified 82 chemically diverse metabolites including withanamides, phenolic acids, sterols, and tocopherols (Bhatia et al. 2013). This plant has been found to contain more than 12 alkaloids, 40 withanolides, and several sitoindosides (Mir et al. 2012). At present, $W$. somnifera is utilized in various herbal medicines, resulting in high demand in a global marketplace.

Due to the large demand of W. somnifera, it is being cultivated in different states of India including Jammu and Kashmir, Himachal Pradesh, Maharashtra, Punjab, Rajasthan, Karnataka, Andhra Pradesh, Madhya Pradesh, Tamil Naidu, Uttar Pradesh, and Gujarat (Kulkarni and Dhir 2008; Kumar et al. 2007; Lal 2015; Meher et al. 2016). In India, the annual production of $W$. somnifera is estimated to be 1500 tonnes, while annual consumption is anticipated to be 7000 tonnes resulting in a substantial demand-supply gap (Kaur et al. 2021b). In addition, $W$. somnifera which is normally propagated by seeds suffers limitations due to the low seed viability, low seed germination percentage, and less seedlings survival rate (Kaur et al. 2021b). Further, the cultivation and its genetic improvement processes are affected owing to its narrow genetic base, self-pollination, long gestation period, and infestation by various pathogens and insects (Singh et al. 2017). All these factors suggest that the conventional methods of propagation of $W$. somnifera and its genetic improvement to meet the commercial demand are difficult to accomplish. Hence, deciphering strategies for their rapid propagation using modern experimental techniques could be beneficial.

Since many years, in vitro propagation through plant tissue culture techniques has proved itself as a reliable and promising tool for clonal propagation of healthy and diseasefree plants throughout the year. In the case of W. somnifera, this technology could be of immense value as it facilitates in generating large-scale healthy, genetically uniform plants with defined chemical content for pre-clinical and translational studies. Overall, the rapid propagation of elite plants will provide high dividends to farmers and the associated herbal industry. In addition, the integration of plant tissue culture with other biotechnological tools can be employed to enhance the commercial value of $W$. somnifera. Thus, the present review provides a summarized view of attempts undertaken for plant cell, tissue and organ culture in W. somnifera. It also highlights the experimental strategies adapted to increase the biosynthesis of pharmaceutically important constituents in this high valued medicinal plant.

\section{In vitro propagation in W. somnifera}

\section{Micropropagation}

In recent years, several efforts have been undertaken to propagate $W$. somnifera employing different explants (Kaur et al. 2017; Singh et al. 2017). The successful micropropagation protocol of $W$. somnifera involves several distinct and interrelated stages. These include (i) initiation of aseptic cultures, (ii) shoot multiplication, (iii) in vitro rooting, (iv) acclimatization of rooted microshoots, and further establishment in field conditions (Fig. 1). Herein, an attempt is made to discuss the current status of work on micropropagation of $W$. somnifera and various factors which greatly influence the different stages of micropropagation.

\section{Initiation of aseptic cultures}

Initiation of aseptic culture is the first and critical stage in successful micropropagation protocol. It comprises explant selection and sterilization. 


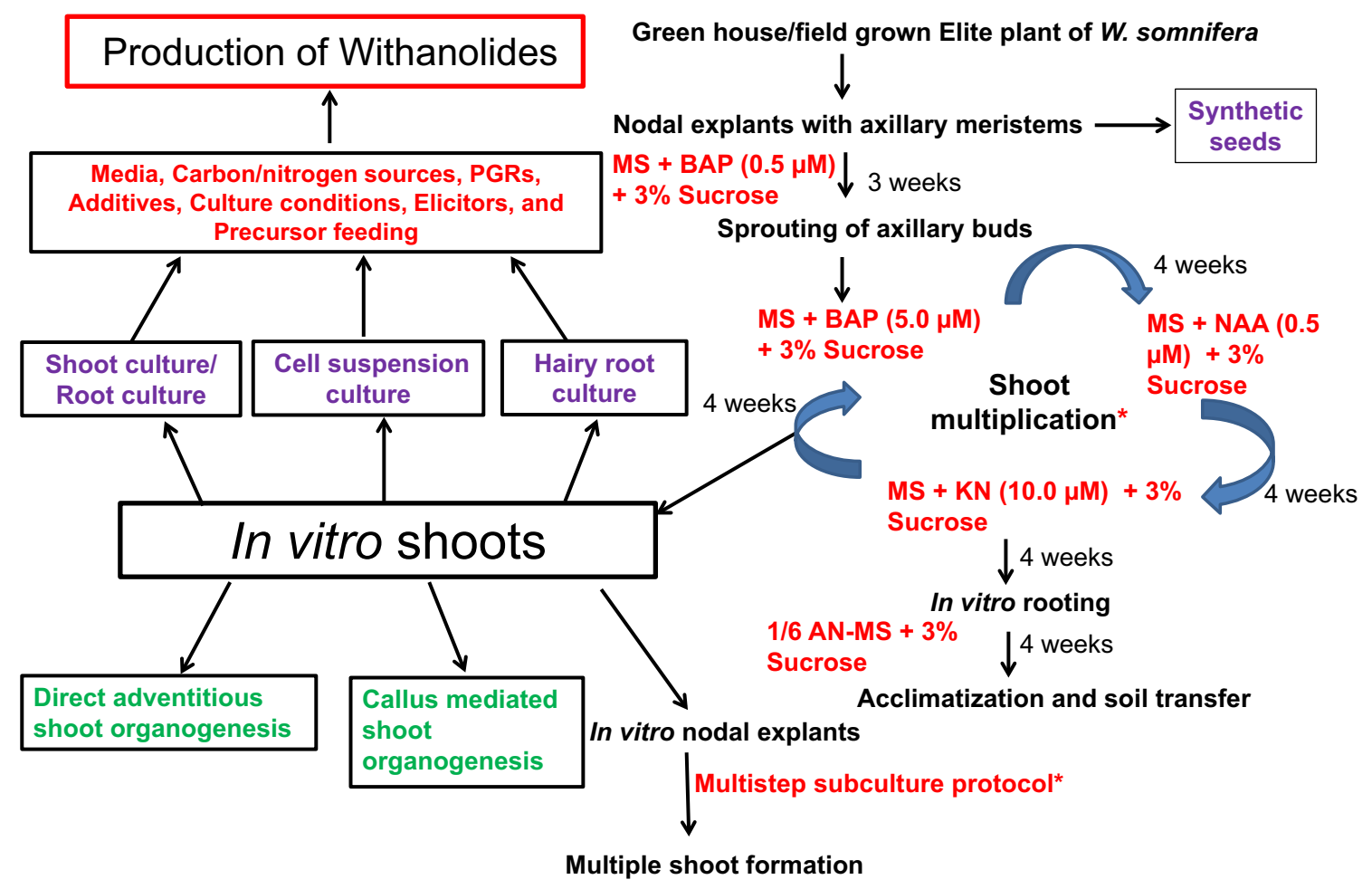

Fig. 1 Plant tissue culture: Means for the production of pharmaceutically important bioactive constituents in W. somnifera

\section{Choice of explant}

The selection of explants largely depends on the objective of the experiment. In the case of W. somnifera, different explants like nodal segments, seeds, and shoot tips were used to initiate aseptic cultures (Table 1). The majority of studies in $W$. somnifera have used nodal segments for the establishment of in vitro cultures.

\section{Surface sterilization of explants}

Several factors including type, concentration, and treatment duration of the sterilizing agents influence the surface sterilization of explants (Wen et al. 2020). The surface sterilization of $W$. somnifera is often accomplished by the use of various sterilizing agents in a step-wise manner. Presterilization of the explants is conducted by washing of explants with distilled water followed by treatment with some commercial detergents (Table 1). Teepol was employed as a detergent at a concentration of 5\% (v/v) for 5-8 min (Nayak et al. 2013; Ray and Jha 2001; Sen and Sharma 1991), although other researchers specified $2.5 \%(\mathrm{v} / \mathrm{v})$ teepol for $5 \mathrm{~min}$ (Sivanandhan et al. 2011, 2015). Labolene (5\%) has also been used for a longer time (10-15 min) for surface sterilization of explants (Fatima et al. 2011; Fatima and Anis 2011, 2012). Besides these, the lower percentage of Tween$20(1 \%)$ for $1 \mathrm{~min}$ was used for the sterilization of nodal segments (Autade et al. 2016) whereas, a higher percentage (10\%) of Tween-20 was also reported for the sterilization of axillary buds in $W$. somnifera for 5 min (Saritha and Naidu 2007). For surface sterilization of explants, various sterilizing agents such as mercuric chloride $\left(\mathrm{HgCl}_{2}\right)$ and sodium hypochlorite $(\mathrm{NaOCl})$ were used in $W$. somnifera (Table 1$)$. Several workers have used different doses of $\mathrm{HgCl}_{2}$ solutions such as $0.01 \%, 0.1 \%$, and $0.2 \%(\mathrm{w} / \mathrm{v})$ for sterilization in W. somnifera (Autade et al. 2016; Kannan and Anbazhakan 2016; Sen and Sharma 1991; Sivanandhan et al. 2011; Supe et al. 2006). The sterilization of explants with $0.4 \%$ $\mathrm{NaOCl}$ has also been documented in $W$. somnifera (Kaur et al. 2021b; Udayakumar et al. 2013).

\section{Critical factors influencing micropropagation}

\section{Medium}

Various types of basal media were employed for experimentspecific purposes in micropropagation of $W$. somnifera and the most frequently used nutrient media is Murashige and Skoog (Murashige and Skoog 1962) medium (Kaur et al. 2017; Singh et al. 2017) (Table 1). In addition, a large number of studies in micropropagation of $W$. somnifera have reported various other types of basal media such as B5 


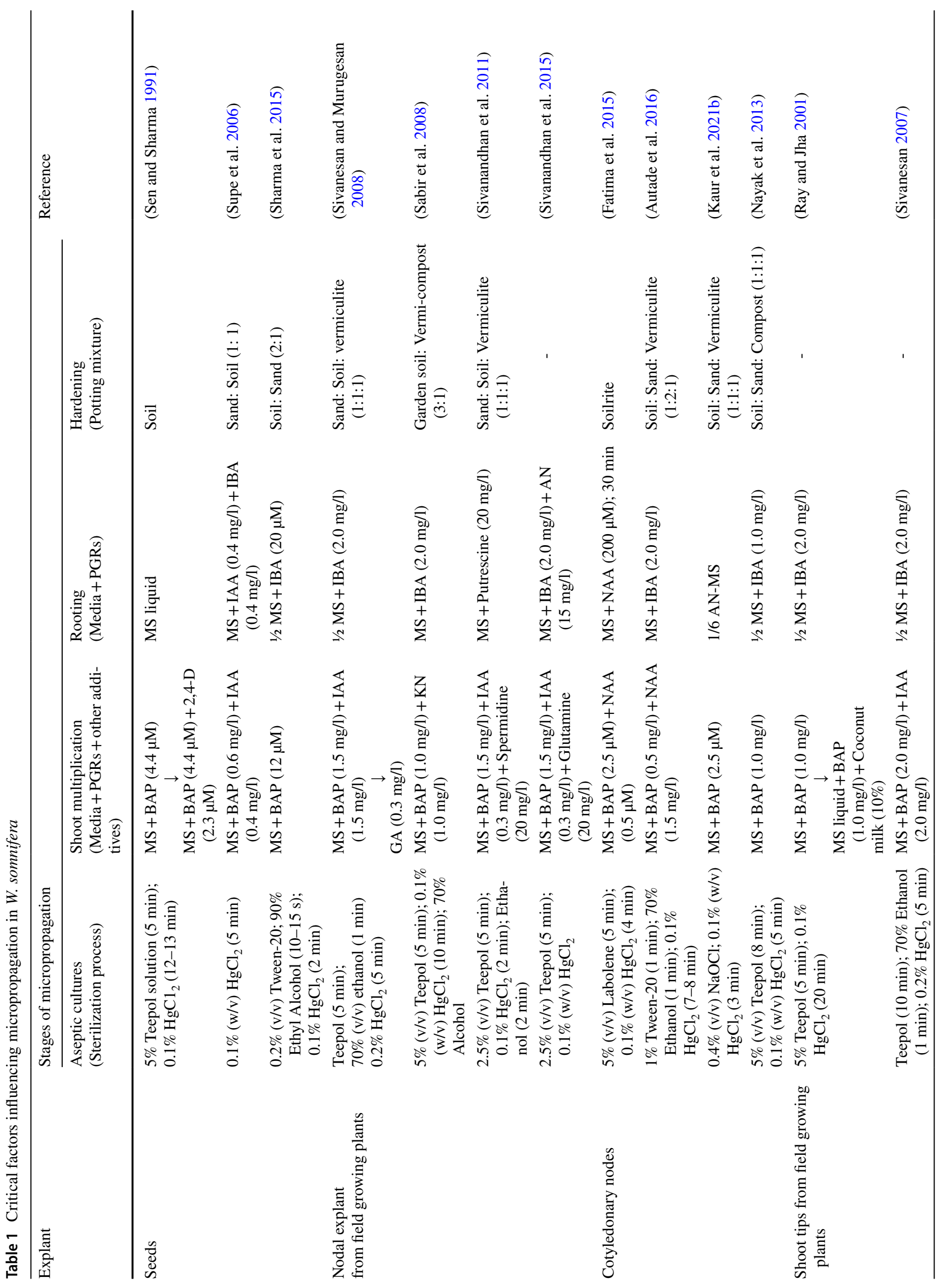




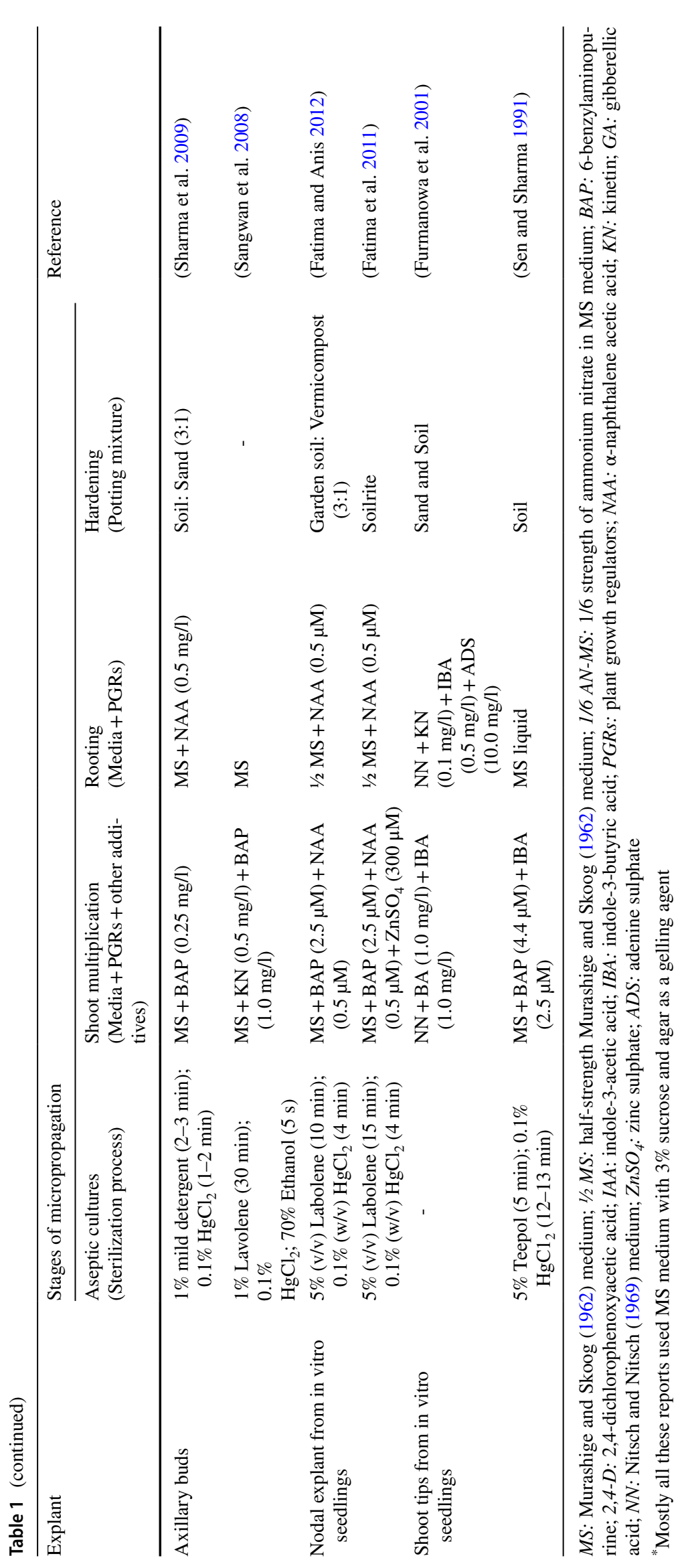


(Gamborg et al. 1968) and Schenk and Hildebrandt (SH) (Schenk and Hildebrandt 1972), Nitsch and Nitsch (NN) (Nitsch and Nitsch 1969), and woody plant medium (WPM) (Lloyd and McCown 1980) by different workers (Fatima et al. 2015; Furmanowa et al. 2001; Namdeo and Ingawale 2020; Shasmita et al. 2018; Sivanesan 2007). MS medium containing plant growth regulators (PGRs) showed the maximum percentage of shoot induction from apical buds in comparison to B5 and SH medium (Sivanesan 2007). This could be due to the moderate salt requirement for shoot proliferation of $W$. somnifera. Furthermore, MS medium was reported to be optimal for shoot multiplication among B5, MS, and WPM medium from nodal segments (Fatima et al. 2015). The improved growth of $W$. somnifera shoots in MS medium could be due to the higher concentration of ammonium and nitrate in comparison to WPM and B5 medium (Ahmad and Anis 2011; Perveen et al. 2011). The use of NN medium enriched with $1.0 \mathrm{mg} / \mathrm{l} \mathrm{BA}$ (6-benzylaminopurine) and $1.0 \mathrm{mg} / \mathrm{l}$ IBA (indole-3-butyric acid) was also used for shoot multiplication (Furmanowa et al. 2001).

The role of different strengths MS medium was also investigated for root induction (Table 1). In certain cases, a half-strength MS (1/2 MS) medium was adopted for in vitro rooting of W. somnifera shoots (Fatima et al. 2011; Fatima and Anis 2012; Kannan and Anbazhakan 2016; Nayak et al. 2013; Saema et al. 2015; Sivanesan 2007). It was observed that a higher percentage of cultures were responded to rooting on $1 / 2$ MS medium (42.5\%) in comparison with fullstrength MS medium when shoots were cultured on the same concentration of auxin i.e. IBA $(20.0 \mu \mathrm{M})$ (Sharma et al. 2015). The higher frequency (100\%) of rooting with the maximum number of roots was also reported on $1 / 2$ MS medium containing IBA $(2.0 \mathrm{mg} / \mathrm{l})$ and $1.5 \%$ sucrose (Sivanesan and Park 2015). It is well known that the culture medium containing a higher level of nutrients with high osmotic potential showed inhibition to root induction (George et al. 2008). This might be the reason for the higher rate of in vitro rooting in the reduced strength of the culture medium. Our research group revealed that $1 / 6$ strength of $\mathrm{NH}_{4} \mathrm{NO}_{3}$ in basal MS medium favors in vitro rooting compared with full-strength MS (Kaur et al. 2021b). This might be due to the fact that nitrogen affects auxin biosynthesis, signaling, and transport in plants (Vega et al. 2019). On contrary, the higher rate of root induction in W. somnifera was also reported in full-strength MS medium containing IBA $(1.0 \mathrm{mg} / \mathrm{l})$ in comparison to the reduced strengths $(1 / 2 \mathrm{MS}$, 1/3 MS, and 1/4 MS) of basal MS medium (Ghimire et al. 2010).

Furthermore, the addition of additives like L- glutamine (Sivanandhan et al. 2015), spermidine (Sivanandhan et al. 2011), $\mathrm{ZnSO}_{4}$ (Fatima et al. 2011), and coconut milk (Ray and Jha 2001) to the nutrient medium improved shoot multiplication in W. somnifera. Moreover, the role of various polyamines such as putrescine, spermine, and spermidine in in vitro rooting was also investigated (Sivanandhan et al. 2011). Among these, putrescine $(20 \mathrm{mg} / \mathrm{l})$ was found effective for in vitro rooting as compared with spermine and spermidine. The addition of $10.0 \mathrm{mg} / \mathrm{l}$ adenine sulphate (Furmanowa et al. 2001) and $15.0 \mathrm{mg} / \mathrm{l}$ ammonium nitrate (Sivanandhan et al. 2015) in IBA supplemented culture medium also influenced the root induction.

\section{Growth regulators}

Growth regulators free basal culture medium is not sufficient for in vitro multiple shoot proliferation. In vitro shoot multiplication is possible with the addition of PGRs in the basal culture medium. In W. somnifera, BAP was favorably used for optimum shoot proliferation either alone (Kannan and Anbazhakan 2016; Nayak et al. 2013; Saema et al. 2015; Sharma et al. 2015, 2009) or in conjunction with different auxins such as indole-3-acetic acid (IAA) (Sivanandhan et al. 2011, 2015; Sivanesan 2007; Sivanesan and Murugesan 2008), IBA (Furmanowa et al. 2001; Sen and Sharma 1991), and $\alpha$-naphthalene acetic acid (NAA) (Fatima et al. 2011; Fatima and Anis 2012; Saritha and Naidu 2007) (Table 1). Furthermore, different types of cytokinins such as kinetin (KN) and thidiazuron (TDZ) were studied for shoot proliferation in W. somnifera (Fatima and Anis 2011; Sangwan et al. 2008; Sivanesan and Park 2015). BAP is most commonly used for shoot multiplication in W. somnifera (Singh et al. 2017) due to high cytokinin activity, accessibility, and relatively inexpensive. Kinetin is a weak cytokinin that promotes shoot multiplication with the addition of BAP in $W$. somnifera (Deka et al. 1999; Mir et al. 2014; Sabir et al. 2008; Sangwan et al. 2008). On the other hand, TDZ (thidiazuron), a substituted phenylurea is an effective cytokinin at very low concentrations for shoot multiplication (Fatima and Anis 2011). This TDZ action is attributed to an intrinsic cytokinin-like activity that inhibits cytokinin oxidases (Mohammadi et al. 2020). Unlike other Solanceaous species, W. somnifera plants are not easy to establish long-term under in vitro conditions. Kaur et al. (2021b) recorded that the repeated culturing of $W$. somnifera shoots in MS medium supplemented with BAP showed a sharp decline in the shoot multiplication index. In addition, prolonged BAP exposure caused morphological changes including leaf yellowing and necrosis, stunted shoot growth, thick stem, and hyperhydricity. The negative influence of BAP could be ascribed to its high stability, which causes an increase in BAP concentration in the microshoots (Kaur et al. 2021b). To overcome this problem, a multistep subculture protocol comprising auxin and cytokinin has been employed. But the rate of shoot multiplication did not increase significantly with each subculture. As a result, it was necessary to fine-tune such protocols using an unconventional cytokinin to improve 
plant multiplication and growth. Recently, our group has investigated the use of novel cytokinin, i.e. meta-Topolin $(m \mathrm{~T})$, BAP analog for shoot multiplication in W. somnifera (Kaur et al. 2021a). $m \mathrm{~T}$ (6-(3-hydroxylbenzylamino) purine) is an aromatic natural cytokinin and isolated from poplar leaves (Chauhan and Taylor, 2018; Strnad et al., 1997). The effective shoot multiplication with the application of $m \mathrm{~T}$ has been reported in various plant species (Behera et al. 2019, 2022; Halder and Ghosh 2021; Kucharska et al. 2020; Naaz et al. 2019) and it also showed a higher efficacy over BAP for shoot multiplication in W. somnifera (Kaur et al. 2021a). This could be because the aromatic side chain has a hydroxyl group, which facilitates the formation of $O$-glycoside. Depending on the requirements, these $O$-glycosides can be easily converted into active nucleotides, nucleosides, or free bases (Shekhawat et al. 2021). For the elongation of proliferated microshoots, the use of gibberellic acid $\left(\mathrm{GA}_{3}\right)$ supplemented MS medium has been recorded in W. somnifera (Sivanesan and Murugesan 2008; Sivanesan and Park 2015).

MS media supplemented with different auxins such as IAA, IBA, and NAA alone or in conjunction with each other was employed for in vitro rooting of microshoots in W. somnifera (Table 1). Auxin promotes lateral root initiation and primordium growth by stimulating cell division, expansion, and differentiation (Kaur et al. 2021b). In previous reports, IBA was favorably used for root induction in $W$. somnifera (Singh et al., 2017; Shasmita et al. 2018). Besides this, IBA in conjunction with other auxins such as IAA (Rani and Grover 1999; Supe et al. 2006) and NAA (Arumugam and Gopinath 2013; Fatima et al. 2011; Fatima and Anis 2012; Sharma et al. 2009) has also been reported for in vitro rooting.

\section{Carbon sources}

Carbon is essential for the growth and development of in vitro grown cultures of many plant species. It is provided in the form of sugars including glucose, maltose, sucrose, and fructose. They serve as energy sources and keep the osmotic balance between both the cell and the external environment in the growth medium (George et al. 2008; Sivanesan and Park 2015). Sucrose is commonly used as a carbohydrate source due to its easy translocatability and resistance to enzymatic degradation (Fatima et al. 2015). Different concentrations $(1 \%, 2 \%, 3 \%, 4 \%, 6 \%$, and $8 \%)$ of sucrose were reported in in vitro propagation studies of $W$. somnifera depending upon the objective of the experiment. $1 \%$ sucrose was used for seed germination (Sen and Sharma 1991; Supe et al. 2006) while 3\% sucrose was used for shoot multiplication through meristem culture (Fatima and Anis 2011, 2012; Saema et al. 2015; Sivanesan and Murugesan 2008). Whereas, the higher concentration (4\%) of sucrose was also reported for shoot multiplication from nodal segments (Sivanandhan et al. 2015). Besides the shoot proliferation, the higher concentration (6\%) of sucrose in MS medium along with BA $(0.3 \mathrm{mg} / \mathrm{l})$ showed in vitro flowering in W. somnifera (Sivanesan and Park 2015) and the same effect of sucrose was also documented in many other plant species (Franklin et al. 2000; Rathore et al. 2013; Sangeetha and Venkatachalam 2014). On the other hand, a lower concentration of sucrose was preferred for in vitro rooting of W. somnifera (Sivanesan and Park 2015). In this report, the maximum root induction was achieved with $1.5 \%$ sucrose over $3 \%$ sucrose in IBA $(2.0 \mathrm{mg} / \mathrm{l})$. This study clues that there is some kind of connection between sucrose concentration and root-promoting PGR i.e. auxin. Sucrose is hydrolyzed into glucose and fructose in the nutrient medium and glucose can regulate auxin biosynthetic genes (YUCCA), transporter (PIN proteins), receptor (TIR1), and genes involved in auxin signaling (GH3, AUX/IAA, and SAUR) resulting in the enhancement in root induction (Mishra et al. 2009).

\section{Status of the medium}

Agar, phytagel, clarigel, and gelrite are used as gelling agents to prepare a semi-solid culture medium (Kaur and Kumar 2020). In the case of W. somnifera, agar and phytagel were used as the gelling agents to support explants. Agar, a polysaccharide obtained from seaweeds is most frequently used for in vitro propagation of W. somnifera due to its convenient gelling properties, stability, and resistance to degradation by plant enzymes (Purohit et al. 2011). However, several limitations including batch-to-batch inconsistency, limited availability, presence of impurities, and inhibition of growth have been recorded on the use of agar in the culture medium (Puchooa et al. 1999). In addition, agar is the most expensive component in plant tissue culture medium and is responsible for around $70-80 \%$ of the total cost (Lozzi et al. 2019). On the other hand, phytagel which is a natural polysaccharide has also been used as a gelling agent in shoot proliferation of $W$. somnifera (Sivanandhan et al. 2011, 2015). To develop the micropropagation protocol for commercialization, the fine-tuning of existing protocols as well as cost reduction is very critical (Pati et al. 2006). The elimination of gelling agents which saves substantial cost has been tried by many researchers in various plant species (Malik et al. 2016; Singh 2018; Vaidya et al. 2019; Wangdi and Sarethy 2016). The liquid culture system has a number of potential benefits including (i) improved plant growth due to increased availability of nutrients and growth regulators, (ii) adequate aeration in a liquid medium which results in the improvement of shoot growth and multiplication, (iii) sterilization by microfiltration, (iv) addition of fresh media without changing the container, and (v) high efficiency of transferring plants to their natural conditions (Lozzi et al. 
2019; Sivanandhan et al. 2013). There are very few reports available on the liquid culture system in $W$. somnifera (Ray and Jha 2001; Sivanandhan et al. 2013). The liquid MS medium supplemented with BAP $(1.0 \mathrm{mg} / \mathrm{l})$ and $10 \%$ coconut milk was found suitable for shoot multiplication (Ray and Jha 2001). In another investigation, shoots cultured on MS liquid medium supplemented with BAP $(0.6 \mathrm{mg} / \mathrm{l})$ and spermidine $(20 \mathrm{mg} / \mathrm{l})$ resulted in increased shoot proliferation (Sivanandhan et al. 2013). However, the higher concentration of BAP caused hyperhydricity of microshoots. In addition, MS liquid medium has also been reported for in vitro rooting in W. somnifera (Govindaraju et al. 2003; Sen and Sharma 1991).

\section{Culture conditions}

For effective in vitro propagation, the microenvironment of the tissue culture room viz., temperature, light intensity, photoperiod, and relative humidity (RH) is essential to maintain cell growth. In the majority of reports published in W. somnifera, the temperature range is similar and lies between the ranges of 20-25 $\pm 1-2^{\circ} \mathrm{C}$ (Kaur et al. 2021b; Sangwan et al. 2008; Sivanandhan et al. 2013). The optimum condition of light intensity of the culture room is imperative for better biomass production as light is a primary factor for photosynthesis in plants. In W. somnifera, the light intensity of the tissue culture room lies between the range of $35-45 \mu \mathrm{mol} /$ $\mathrm{m}^{2} / \mathrm{sec}$ (Singh et al. 2017). The higher $\left(60 \mu \mathrm{mol} / \mathrm{m}^{2} / \mathrm{sec}\right.$ ) light intensity was also reported for multiple shoot induction (Saema et al. 2015). In the majority of the experiments, $16 \mathrm{~h}$ light/8 h dark conditions were most commonly executed. However, $12 \mathrm{~h}$ light/ $12 \mathrm{~h}$ dark and $20 \mathrm{~h}$ light $/ 4 \mathrm{~h}$ dark conditions were also reported for shoot multiplication (Furmanowa et al. 2001; Saritha and Naidu 2007). Further, the relative humidity $(\mathrm{RH})$ in the tissue culture room was kept between 50-70\% in W. somnifera (Kaur et al. 2021b; Saritha and Naidu 2007; Sivanandhan et al. 2015).

\section{Hardening and field establishment}

Hardening is the last step of in vitro propagation study. Successful acclimatization of in vitro raised plants depends on various factors such as the genotype of the plant, potting mixture, light intensity, and humidity conditions of the greenhouse (da Silva et al. 2017). Different research groups working on $W$. somnifera employed different approaches to harden tissue culture-raised plants. Many different kinds of potting mixes either individually or in combination were used to acclimatize $W$. somnifera (Table 1). A lower percentage of survival (20\%) was achieved when in vitro propagated plants were transferred to soil (Sen and Sharma 1991). Whereas, the higher percentage survival (83-100\%) was recorded when the soil was mixed with sand to acclimatize tissue culture raised plants (Furmanowa et al. 2001; Kulkarni et al. 1996, 2000; Rani and Grover 1999; Sharma et al. 2015, 2009; Supe et al. 2006). This might be attributed to the sand's high porosity and rate of percolation. Further, a high survival rate was also recorded on soilrite, soil: sand: vermiculite, garden soil: vermicompost, sand: soil: compost, soil: leaf manure, soilrite: soil: compost, vermiculite: perlite, cow dung: red soil, garden soil: sand: farmyard manure, river sand: soil: vermicompost, and agropeat (Shasmita et al. 2018). Overall, these reports suggested that the potting mixture containing soil, sand, and vermiculite facilitated $100 \%$ successful acclimatization of micropropagated plants.

\section{Clonal fidelity assessment of micropropagated shoots}

Various approaches such as molecular markers, morphophysiological, cytological, and biochemical assays were used to evaluate the genetic fidelity of in vitro propagated plants (Gantait et al. 2015). Among these, molecular markers are the method of choice because they are simple, quick, and only require a small quantity of plant material (Kaur et al. 2021b). There are a large number of reports available on micropropagation of W. somnifera. However, the genetic fidelity of regenerants is carried out in a few reports only (Fatima et al. 2015; Kaur et al. 2021b; Mallubhotla et al. 2008; Nayak et al. 2013). To evaluate the genetic uniformity of nodal explant-based in vitro propagated plants in $W$. somnifera, OPA 04, OPA 09, HBV5, and HVR were selected based on banding pattern out of 20 RAPD (Random amplified polymorphic DNA) and 3 DAMD (Directed amplification of minisatellite DNA) primers (Fatima et al. 2015). The banding pattern profiles of all the micropropagated plants and mother plant were monomorphic. Further, the clonal fidelity of in vitro propagated plants from cotyledonary nodes of W. somnifera was also carried out using ISSR (Inter simple sequence repeats) and RAPD markers (Nayak et al. 2013). Amplified products generated from primers showed homogenous bands, thus validating the true-to-type nature of in vitro propagated plants. Furthermore, three different PCR-based molecular markers including ISSR, RAPD, and SCoT (Start codon targeted) were employed to access the clonal fidelity of in vitro grown plants of W. somnifera for 3 consecutive years (Kaur et al. 2021b).

\section{In vitro regeneration in $W$. somnifera}

An effective and reproducible regeneration system is required for the implementation of biotechnological techniques used for plant improvement programs. The addition of PGRs in the culture media is the most important factor for organogenesis. However, the type and concentration of 
growth regulators added to the nutrient medium determine whether an explant regenerates by direct or indirect mode of shoot organogenesis.

Unlike other solanaceous species (Nicotiana, Petunia, and Datura), Withania is a highly recalcitrant species with regard to its capacity for in vitro plant regeneration and genetic transformation (Bomzan et al. 2020; Yildiz 2012). It is well known that the plants that produce high levels of secondary metabolites are recalcitrant to plant regeneration (Benson 2000; Pandey et al. 2010). There are only a few studies on direct shoot regeneration in W. somnifera (Table 2) and leaves were most frequently used as explants (Ghimire et al. 2010; Joshi and Padhya 2010; Kaur et al. 2021a; Kumar et al. 2011; Logesh et al. 2010). Few studies were also available on the use of other explants, such as epicotyl (Udayakumar et al. 2013), petiole (Ghimire et al. 2010), and internodes (Kulkarni et al. 2000) for direct shoot organogenesis. The different types of basal medium (MS, B5, and SH) and carbon sources (sucrose, fructose, and maltose) influence the shoot regeneration frequency from leaf and petiole explants in W. somnifera (Ghimire et al. 2010). They investigated that MS medium with 3\% sucrose was optimum for the induction of direct adventitious shoots. Similarly, many other researchers have also reported the use of 3\% sucrose for direct shoot regeneration (Joshi and Padhya 2010; Kaur et al. 2021a; Kumar et al. 2011). On contrary, $2 \%$ sucrose supplemented MS medium was also recorded for shoot organogenesis (Kulkarni et al. 1996, 2000). Apart from the culture media composition, PGRs are also critical in shoot regeneration. In most of the studies, BAP was most commonly used cytokinin either alone (Ghimire et al. 2010; Kaur et al. 2021a; Kulkarni

Table 2 Factors influencing direct adventitious shoot organogenesis in W. somnifera

\begin{tabular}{|c|c|c|c|c|c|}
\hline \multirow[t]{2}{*}{ Explant } & \multicolumn{3}{|l|}{ Direct shoot organogenesis } & \multirow{2}{*}{$\begin{array}{l}\text { Rooting } \\
\text { (Medium + PGRs) }\end{array}$} & \multirow[t]{2}{*}{ Reference } \\
\hline & Media + PGRs & $\begin{array}{l}\text { Shoot regenera- } \\
\text { tion frequency } \\
(\%)\end{array}$ & $\begin{array}{l}\text { No. of } \\
\text { shoots/ } \\
\text { explant }\end{array}$ & & \\
\hline \multirow[t]{3}{*}{$\begin{array}{l}\text { Leaves from in vitro } \\
\text { seedlings }\end{array}$} & $\begin{array}{l}\mathrm{MS}+\mathrm{BAP}(8.8 \mu \mathrm{M})+\mathrm{IAA} \\
\quad(7.99 \mu \mathrm{M})\end{array}$ & $56.65 \%$ & 16 & $\mathrm{MS}+\mathrm{BAP}(0.044 \mu \mathrm{M})$ & (Kulkarni et al. 1996) \\
\hline & $\mathrm{MS}+\mathrm{BAP}(2.0 \mathrm{mg} / \mathrm{l})$ & - & 23 & $\mathrm{MS}+\mathrm{IBA}(1.0 \mathrm{mg} / \mathrm{l})$ & (Ghimire et al. 2010) \\
\hline & $\begin{array}{c}\mathrm{MS}+\mathrm{BAP} \\
\quad(2.0 \mathrm{mg} / \mathrm{l})+\mathrm{IAA} \\
(0.5 \mathrm{mg} / \mathrm{l}) \\
\downarrow \\
\downarrow \\
\mathrm{MS}+\mathrm{GA}_{3}(0.5 \mathrm{mg} / \mathrm{l})\end{array}$ & - & - & $\mathrm{MS}+\mathrm{IBA}(0.5 \mathrm{mg} / \mathrm{l})$ & (Logesh et al. 2010) \\
\hline $\begin{array}{l}\text { Leaves from in vitro grown } \\
\text { shoots }\end{array}$ & $\mathrm{MS}+\mathrm{BAP}(10.0 \mu \mathrm{M})$ & $92.58 \%$ & 23.13 & $\mathrm{MS}+\mathrm{IAA}(10.0 \mu \mathrm{M})$ & (Kaur et al. 2021a) \\
\hline $\begin{array}{l}\text { Leaves } \\
\text { from field growing plants }\end{array}$ & $\begin{array}{l}\mathrm{MS}+\mathrm{BAP}(4.0 \mu \mathrm{M})+\mathrm{KN} \\
\quad(4.0 \mu \mathrm{M})\end{array}$ & $90 \%$ & 12.1 & $\begin{array}{l}1 / 2 \mathrm{MS}+\mathrm{BA} \\
\quad(0.5 \mu \mathrm{M})+\text { Sucrose }(1 \%)\end{array}$ & (Joshi and Padhya 2010) \\
\hline \multirow[t]{2}{*}{$\begin{array}{l}\text { Internode explants from } \\
\text { in vitro seedlings }\end{array}$} & $\begin{array}{c}\mathrm{MS}+\mathrm{BAP}(5.0 \mathrm{mg} / \mathrm{l}) \\
\downarrow \\
\text { MS + BAP }(0.01 \mathrm{mg} / \mathrm{l})\end{array}$ & - & 10.22 & $\mathrm{MS}+\mathrm{BAP}(0.01 \mathrm{mg} / \mathrm{l})$ & (Kulkarni et al. 2000) \\
\hline & $\begin{array}{l}\mathrm{MS}+\mathrm{KN} \\
\quad(2.0 \mathrm{mg} / \mathrm{l})+\mathrm{NAA} \\
\quad(0.5 \mathrm{mg} / \mathrm{l}) \\
+\mathrm{GA}_{3}(0.3 \mathrm{mg} / \mathrm{l})\end{array}$ & $96 \%$ & 22.8 & $\begin{array}{l}1 / 2 \mathrm{MS}+\mathrm{IBA} \\
\quad(2.0 \mathrm{mg} / \mathrm{l})+\text { Sucrose } \\
(1.5 \%)\end{array}$ & (Sivanesan and Park 2015) \\
\hline $\begin{array}{l}\text { Nodal segments from } \\
\text { in vitro seedlings }\end{array}$ & $\begin{array}{l}\mathrm{MS}+\mathrm{TDZ} \\
\quad(0.2 \mathrm{mg} / \mathrm{l})+\text { Sucrose } \\
\quad(2 \%) \\
\quad \downarrow \\
1 / 2 \mathrm{MS}\end{array}$ & - & 10.1 & $1 / 2 \mathrm{MS}$ & (Kulkarni et al. 2000) \\
\hline $\begin{array}{l}\text { Epicotyls from in vitro } \\
\text { seedlings }\end{array}$ & $\begin{array}{c}\mathrm{MS}+\mathrm{BAP} \\
(2.0 \mathrm{mg} / \mathrm{l})+\mathrm{IAA} \\
(0.2 \mathrm{mg} / \mathrm{l}) \\
\downarrow \\
\begin{array}{c}\downarrow \\
\mathrm{MS}+\mathrm{GA}_{3}(1.0 \mathrm{mg} / \mathrm{l})\end{array}\end{array}$ & $85 \%$ & 6.6 & $\mathrm{MS}+\mathrm{IBA}(0.8 \mathrm{mg} / \mathrm{l})$ & (Udayakumar et al. 2013) \\
\hline Leaf petiole & $\mathrm{MS}+\mathrm{BAP}(2.0 \mathrm{mg} / \mathrm{l})$ & - & 3.67 & $\mathrm{MS}+\mathrm{IBA}(1.0 \mathrm{mg} / \mathrm{l})$ & (Ghimire et al. 2010) \\
\hline
\end{tabular}

*Mostly all these reports used MS medium with 3\% sucrose and agar as a gelling agent

MS: Murashige and Skoog (1962) medium; PGRs: plant growth regulators; IAA: indole-3-acetic acid; $G A_{3}$ : gibberellic acid; BAP: 6-benzylaminopurine; $I B A$ : indole-3-butyric acid; TDZ: thidiazuron; $1 / 2 M S$ : half-strength Murashige and Skoog (1962) medium; $K N$ : kinetin 
et al. 2000) or in conjunction with kinetin (Joshi and Padhya 2010) or IAA (Kulkarni et al. 1996; Kumar et al. 2011; Logesh et al. 2010; Udayakumar et al. 2013) in W. somnifera. In most of the reports, the highest shoot regeneration frequency ( $>80 \%$ ) was obtained on MS medium fortified with BAP alone or in conjunction with auxin and another mild cytokinin irrespective of the explant type (Table 2). These studies revealed the importance of BAP in the shoot regeneration medium for in vitro direct shoot bud induction using various explants in $W$. somnifera. The types and orientation of the explant were shown to have a substantial impact on the shoot regeneration frequency (Ghimire et al. 2010). They reported the higher shoot regeneration frequency from leaf segments in comparison to petiole explant. This might be owing to the basipetal transport of endogenous auxins. They also investigated that the petioles responded to shoot regeneration from their petiolar region due to higher density of vascular tissue, phytohormones levels, and metabolites (Ghimire et al. 2010). Additionally, the role of culture vessels in plant tissue culture has long been documented. The leaves inoculated in glass culture tubes showed maximum shoot induction. On the other hand, only callus formation was recorded while leaf explants were inoculated on plastic Petri-dishes (Kulkarni et al. 1996). This might be owing to the high amount of ethylene accumulation in glass tubes that could promote the shoot bud induction through controlling cell division in the induction phase (Shasmita et al. 2018).

In Indirect shoot organogenesis of W. somnifera, different explants such as the leaf, cotyledons, epicotyl, hypocotyl, axillary shoots, shoot tips, axillary leaves, and internodes have been used (Table 3). The leaves and nodal explants were commonly employed for indirect shoot organogenesis (Arumugam and Gopinath 2013; Dewir et al. 2010; Rani et al. 2016; Shukla et al. 2010; Waman et al. 2011). Further, MS medium with 3\% sucrose and 0.6-0.8\% agar was mostly reported for indirect shoot organogenesis. Among the different plant growth regulators, 2,4-D alone or in conjunction with $\mathrm{KN}$ was shown to be efficient for inducing callus from different explants in W. somnifera (Shasmita et al. 2018; Singh et al. 2017). Furthermore, the callus-mediated shoot regeneration was recorded in BAP alone or in conjunction with IAA or NAA, or IBA (Shasmita et al. 2018). In few reports, the same composition of callus induction medium has also been used for shoot regeneration (Rani and Grover 1999; Shukla et al. 2010).

\section{Advancements in the production of withanolides}

Plant cell, tissue and organ cultures have evolved as promising resources for the production of pharmaceutically important secondary metabolites owing to its advantages over traditional cultivation including a year round-system for the synthesis of pharmaceutically important compounds without any geographical, seasonal, and environmental variations, simplicity in the extraction of metabolites, and high yields, etc. (Gonçalves and Romano 2018; Isah et al. 2018). In the past few years, various approaches have been hypothesized and experimented with to enhance the biosynthesis of withanolides in W. somifera (Fig. 1). Some of these include tissue and organ culture, hairy root culture, cell suspension culture, elicitation, precursor feeding, large-scale cultivation in a bioreactor system, and biotransformation (Namdeo and Ingawale 2020). In this review, we discuss tissue and organ culture as one of the approaches for increasing withanolides production in W. somnifera.

\section{Critical factors influencing withanolides production in tissue and organ culture}

Different factors such as type of explants (Sharada et al. 2007; Sabir et al. 2013; Sivanandhan et al. 2011), media (Praveen and Murthy 2010; Ray and Jha 2001), growth regulators (Adil et al. 2019; Rangaraju et al. 2018; Ray and Jha 2001; Sivanandhan et al. 2012a, 2013), carbon and nitrogen sources (Ray and Jha 2001; Sivanandhan et al. 2015), the status of the medium (Mir et al. 2014; Sivanandhan et al. 2013; Ray and Jha 2001; Senthil et al. 2015; Rangaraju et al. 2019, 2018); additives (Ray and Jha 1991; Sivanandhan et al. 2013), and elicitors (Sivanandhan et al. 2012a, 2012b) influence withanolides production in the plant tissue and organ cultures of $W$. somnifera (Table 4). An attempt is made here to discuss various factors that have a significant impact on the production of withanolides.

\section{Type of explants}

The selection of fast-growing in vitro cultures is an important factor to produce a higher amount of desired products (Smetanska 2008). Sharada and the group analyzed the synthesis of withanolides from different explants of W. somnifera (Sharada et al. 2007). They observed the highest level of withanolides from cultures established from leaf explants in comparison to shoot and root cultures. This could be due to the different morphologies and intrinsic biosynthetic capabilities that produce a wide range of secondary metabolite content. Further, Sivanandhan et al. (2011) recorded that the leaves and roots of in vitro grown cultures of $W$. somnifera contained higher content of withanolides, withanone, and withaferin A in comparison to stem explant. Sabir et al. (2013) also observed the maximum content of withanolides 
Table 3 Factors influencing callus mediated shoot organogenesis in W. somnifera

\begin{tabular}{|c|c|c|c|c|}
\hline Explant & $\begin{array}{l}\text { Callus induction } \\
\text { (Media + PGRs) }\end{array}$ & $\begin{array}{l}\text { Shoot bud induction } \\
\text { (Media + PGRs) }\end{array}$ & Rooting (Media + PGRs) & Reference \\
\hline \multirow[t]{2}{*}{$\begin{array}{l}\text { Leaf segments from field- } \\
\text { grown plants }\end{array}$} & $\begin{array}{l}\mathrm{MS}+2,4-\mathrm{D} \\
\quad(2.0 \mathrm{mg} / \mathrm{l})+\mathrm{KN} \\
(0.2 \mathrm{mg} / \mathrm{l})\end{array}$ & $\begin{array}{l}\mathrm{MS}+2,4-\mathrm{D} \\
\quad(2.0 \mathrm{mg} / \mathrm{l})+\mathrm{KN} \\
(0.2 \mathrm{mg} / \mathrm{l})\end{array}$ & $\begin{array}{l}\mathrm{MS}+\mathrm{IBA}(2.0 \mathrm{mg} / \mathrm{l})+\mathrm{IAA} \\
\quad(2.0 \mathrm{mg} / \mathrm{l})\end{array}$ & (Rani and Grover 1999) \\
\hline & $\begin{array}{l}\mathrm{MS}+\mathrm{KN} \\
\quad(0.5 \mathrm{mg} / \mathrm{l})+2,4-\mathrm{D} \\
(2.0 \mathrm{mg} / \mathrm{l})\end{array}$ & - & - & (Rani et al. 2016) \\
\hline $\begin{array}{l}\text { Nodal segments from field- } \\
\text { grown plants }\end{array}$ & $\begin{array}{l}\mathrm{MS}+\mathrm{BAP}(4.5 \mu \mathrm{M})+\mathrm{KN} \\
\quad(1.0 \mu \mathrm{M})+\mathrm{NAA} \\
(0.5 \mu \mathrm{M})\end{array}$ & $\begin{array}{l}\mathrm{MS}+\mathrm{BAP}(9.0 \mu \mathrm{M})+\mathrm{IAA} \\
\quad(1.0 \mu \mathrm{M})\end{array}$ & MS & $\begin{array}{l}\text { (De Silva and Senarath } \\
\text { 2009) }\end{array}$ \\
\hline $\begin{array}{l}\text { Internodal segments from } \\
\text { field grown plants }\end{array}$ & $\mathrm{MS}+2,4-\mathrm{D}(2.26 \mu \mathrm{M})$ & $\begin{array}{l}\mathrm{MS}+\mathrm{BAP} \\
\quad(4.44 \mu \mathrm{M})+\mathrm{IAA} \\
(0.57 \mu \mathrm{M})\end{array}$ & $1 / 2 \mathrm{MS}+\mathrm{IBA}(9.84 \mu \mathrm{M})$ & (Manickam et al. 2000) \\
\hline \multirow[t]{2}{*}{$\begin{array}{l}\text { Shoot apex from field- } \\
\text { grown plants }\end{array}$} & $\begin{array}{l}\mathrm{MS}+2,4-\mathrm{D} \\
\quad(1.0 \mathrm{mg} / \mathrm{l})+\mathrm{BAP} \\
(2.0 \mathrm{mg} / \mathrm{l})\end{array}$ & - & - & (Rani et al. 2016) \\
\hline & $\begin{array}{l}\mathrm{MS}+\mathrm{KN}(1.0 \mu \mathrm{M})+, \\
\mathrm{BAP}(4.5 \mu \mathrm{M})+\mathrm{NAA} \\
(1.5 \mu \mathrm{M})\end{array}$ & $\begin{array}{l}\mathrm{MS}+\mathrm{BAP}(9.0 \mu \mathrm{M})+\mathrm{IAA} \\
\quad(1.0 \mu \mathrm{M})\end{array}$ & - & $\begin{array}{l}\text { (De Silva and Senarath } \\
\text { 2009) }\end{array}$ \\
\hline Axillary shoots & $\begin{array}{l}\mathrm{MS}+2,4-\mathrm{D} \\
\quad(2.0 \mathrm{mg} / \mathrm{l})+\mathrm{KN} \\
(0.2 \mathrm{mg} / \mathrm{l})\end{array}$ & $\mathrm{MS}+\mathrm{BAP}(2.0 \mathrm{mg} / \mathrm{l})$ & $\begin{array}{l}\mathrm{MS}+\mathrm{IBA}(2.0 \mathrm{mg} / \mathrm{l})+\mathrm{IAA} \\
\quad(2.0 \mathrm{mg} / \mathrm{l})\end{array}$ & (Rani and Grover 1999) \\
\hline \multirow[t]{5}{*}{$\begin{array}{l}\text { Leaf discs from in vitro } \\
\text { seedlings }\end{array}$} & $\begin{array}{l}\mathrm{MS}+\mathrm{BAP}(2 \mathrm{mg} / \mathrm{l})+\mathrm{IAA} \\
\quad(0.5 \mathrm{mg} / \mathrm{l})\end{array}$ & $\begin{array}{l}\mathrm{MS}+\mathrm{BAP}(2 \mathrm{mg} / \mathrm{l})+\mathrm{IAA} \\
\quad(0.5 \mathrm{mg} / \mathrm{l})\end{array}$ & MS & (Dewir et al. 2010) \\
\hline & $\begin{array}{l}\mathrm{MS}+\mathrm{BAP} \\
\quad(1.0 \mathrm{mg} / \mathrm{l})+2,4-\mathrm{D} \\
(1.0 \mathrm{mg} / \mathrm{l})\end{array}$ & $\begin{array}{l}\mathrm{MS}+\mathrm{BA}(2.0 \mathrm{mg} / \mathrm{l})+ \\
\mathrm{NAA}(1.0 \mathrm{mg} / \mathrm{l})\end{array}$ & $\mathrm{MS}+\mathrm{IBA}(2.0 \mathrm{mg} / \mathrm{l})$ & (Rout et al. 2011) \\
\hline & $\mathrm{MS}+2,4-\mathrm{D}(3.0 \mathrm{mg} / \mathrm{l})$ & $\mathrm{MS}+\mathrm{BAP}(4.0 \mathrm{mg} / \mathrm{l})$ & MS + NAA (10.0 mg/l) & $\begin{array}{l}\text { (Arumugam and Gopinath } \\
\text { 2013) }\end{array}$ \\
\hline & $\begin{array}{l}\mathrm{MS}+2,4-\mathrm{D} \\
(3.0 \mathrm{mg} / \mathrm{l})\end{array}$ & $\mathrm{MS}+\mathrm{BAP}(4.0 \mathrm{mg} / \mathrm{l})$ & $\mathrm{MS}$ + NAA $(4.0 \mathrm{mg} / \mathrm{l})$ & $\begin{array}{l}\text { (Arumugam and Gopinath } \\
\text { 2013) }\end{array}$ \\
\hline & $\begin{array}{l}\mathrm{MS}+2,4-\mathrm{D} \\
\quad(0.5 \mathrm{mg} / \mathrm{l})+\mathrm{KN} \\
(0.2 \mathrm{mg} / \mathrm{l})\end{array}$ & $\begin{array}{l}\mathrm{MS}+\mathrm{BAP} \\
\quad(0.5 \mathrm{mg} / \mathrm{l})+\mathrm{IBA} \\
(0.2 \mathrm{mg} / \mathrm{l})\end{array}$ & MS + IBA (0.5 mg/l) & (Chakraborty et al. 2013) \\
\hline $\begin{array}{l}\text { Hypocotyl from in vitro } \\
\text { seedlings }\end{array}$ & $\mathrm{MS}+2,4-\mathrm{D}(3.0 \mathrm{mg} / \mathrm{l})$ & $\mathrm{MS}+\mathrm{BAP}(2.0 \mathrm{mg} / \mathrm{l})$ & $\mathrm{MS}+\mathrm{NAA}(5.0 \mathrm{mg} / \mathrm{l})$ & $\begin{array}{l}\text { (Arumugam and Gopinath } \\
\text { 2013) }\end{array}$ \\
\hline \multirow[t]{2}{*}{$\begin{array}{l}\text { Epicotyl in vitro } \\
\text { seedlings }\end{array}$} & $\mathrm{MS}+2,4-\mathrm{D}(3.0 \mathrm{mg} / \mathrm{l})$ & $\mathrm{MS}+\mathrm{BAP}(4.0 \mathrm{mg} / \mathrm{l})$ & $\mathrm{MS}+\mathrm{NAA}(5.0 \mathrm{mg} / \mathrm{l})$ & $\begin{array}{l}\text { (Arumugam and Gopinath } \\
\text { 2013) }\end{array}$ \\
\hline & $\mathrm{MS}+\mathrm{NAA}(1.0 \mathrm{mg} / \mathrm{l})$ & $\mathrm{MS}+\mathrm{BAP}(1.0 \mathrm{mg} / \mathrm{l})$ & $\mathrm{MS}+\mathrm{IBA}(2.0 \mathrm{mg} / \mathrm{l})$ & (Waman et al. 2011) \\
\hline \multirow[t]{3}{*}{$\begin{array}{l}\text { Nodal segments from } \\
\text { in vitro seedlings }\end{array}$} & $\mathrm{MS}+\mathrm{KN}(1.0 \mathrm{mg} / \mathrm{l})$ & $\begin{array}{c}\mathrm{MS}+\mathrm{KN}(1.0 \mathrm{mg} / \mathrm{l}) \\
\downarrow \\
\mathrm{KN}(0.5 \mathrm{mg} / \mathrm{l})\end{array}$ & $\mathrm{MS}+\mathrm{IAA}(0.5 \mathrm{mg} / \mathrm{l})$ & (Shukla et al. 2010) \\
\hline & $\mathrm{MS}+\mathrm{NAA}(2.0 \mathrm{mg} / \mathrm{l})$ & $\mathrm{MS}+\mathrm{BAP}(2.0 \mathrm{mg} / \mathrm{l})$ & $\mathrm{MS}+\mathrm{IBA}(2.0 \mathrm{mg} / \mathrm{l})$ & (Waman et al. 2011) \\
\hline & $\begin{array}{l}\mathrm{MS}+2,4-\mathrm{D} \\
\quad(2.0 \mathrm{mg} / \mathrm{l})+\mathrm{KN} \\
(0.2 \mathrm{mg} / \mathrm{l})\end{array}$ & $\begin{array}{l}\mathrm{MS}+\mathrm{BAP} \\
\quad(1.0 \mathrm{mg} / \mathrm{l})+\mathrm{IAA} \\
\quad(0.2 \mathrm{mg} / \mathrm{l}) \\
\downarrow \\
\mathrm{MS}^{\downarrow}+\mathrm{GA}_{3}(1.0 \mathrm{mg} / \mathrm{l})\end{array}$ & MS + IBA $(0.8$ mg/l) & (Udayakumar et al. 2014) \\
\hline
\end{tabular}

*Mostly all these reports used MS medium with $3 \%$ sucrose and agar as a gelling agent

$M S$, Murashige and Skoog (1962) medium; 2,4-D, 2,4 dichlorophenoxyacetic acid; PGRs, plant growth regulators; KN, kinetin; IAA, indole3 -acetic acid; $I B A$, indole-3-butyric acid; $B A P, 6$-benzylaminopurine; $N A A, \alpha$-naphthalene acetic acid; $G A_{3,}$ gibberellic acid

in in vitro shoots of $W$. somnifera, when compared with in vitro root and callus tissues. The differences in withanolides content might be due to the morphogenic transitions and the metabolic switching of withanogenesis is intricately linked to the differentiation-dedifferentiation-regeneration phases that alter the phytochemical composition. 


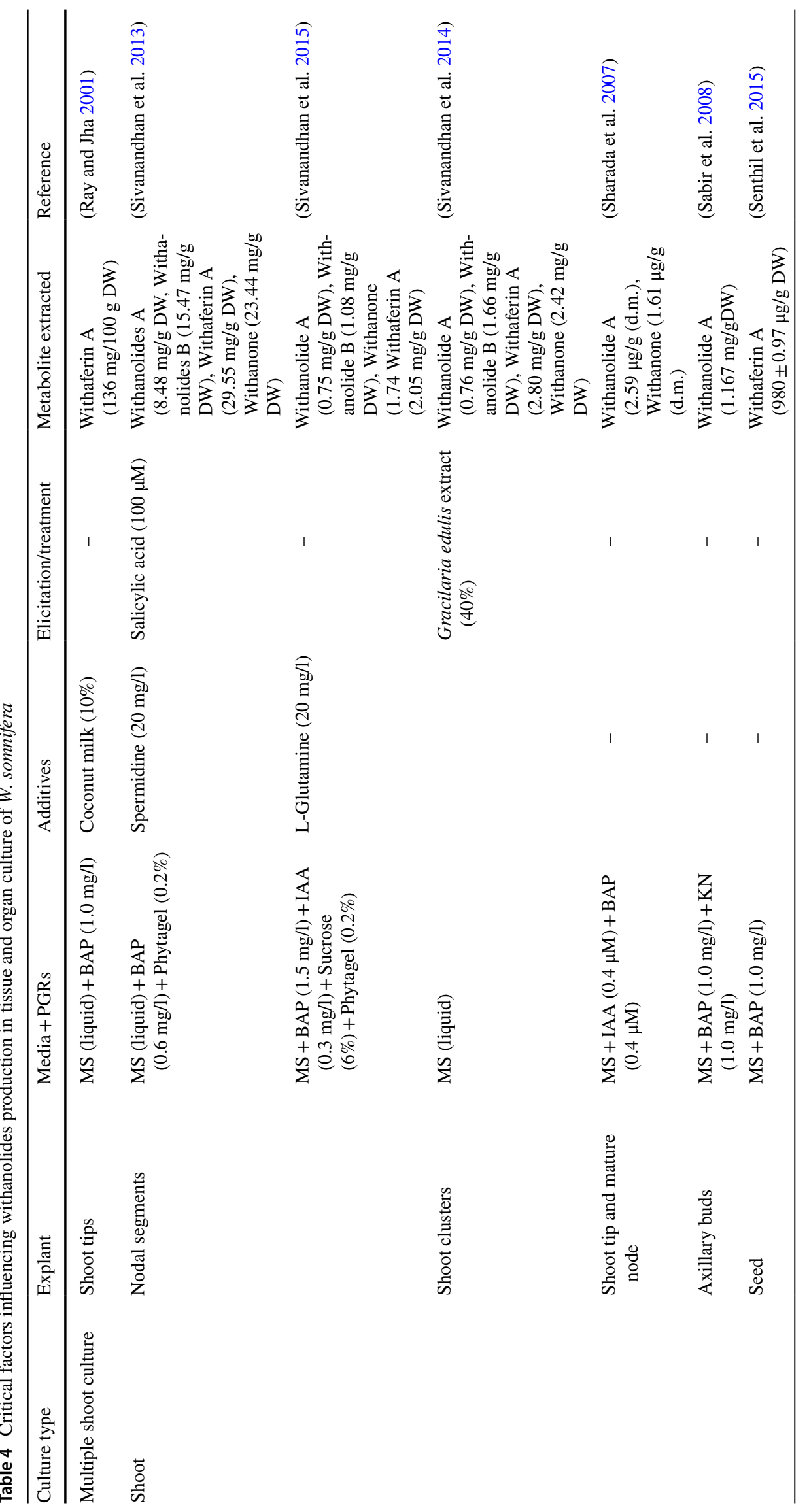




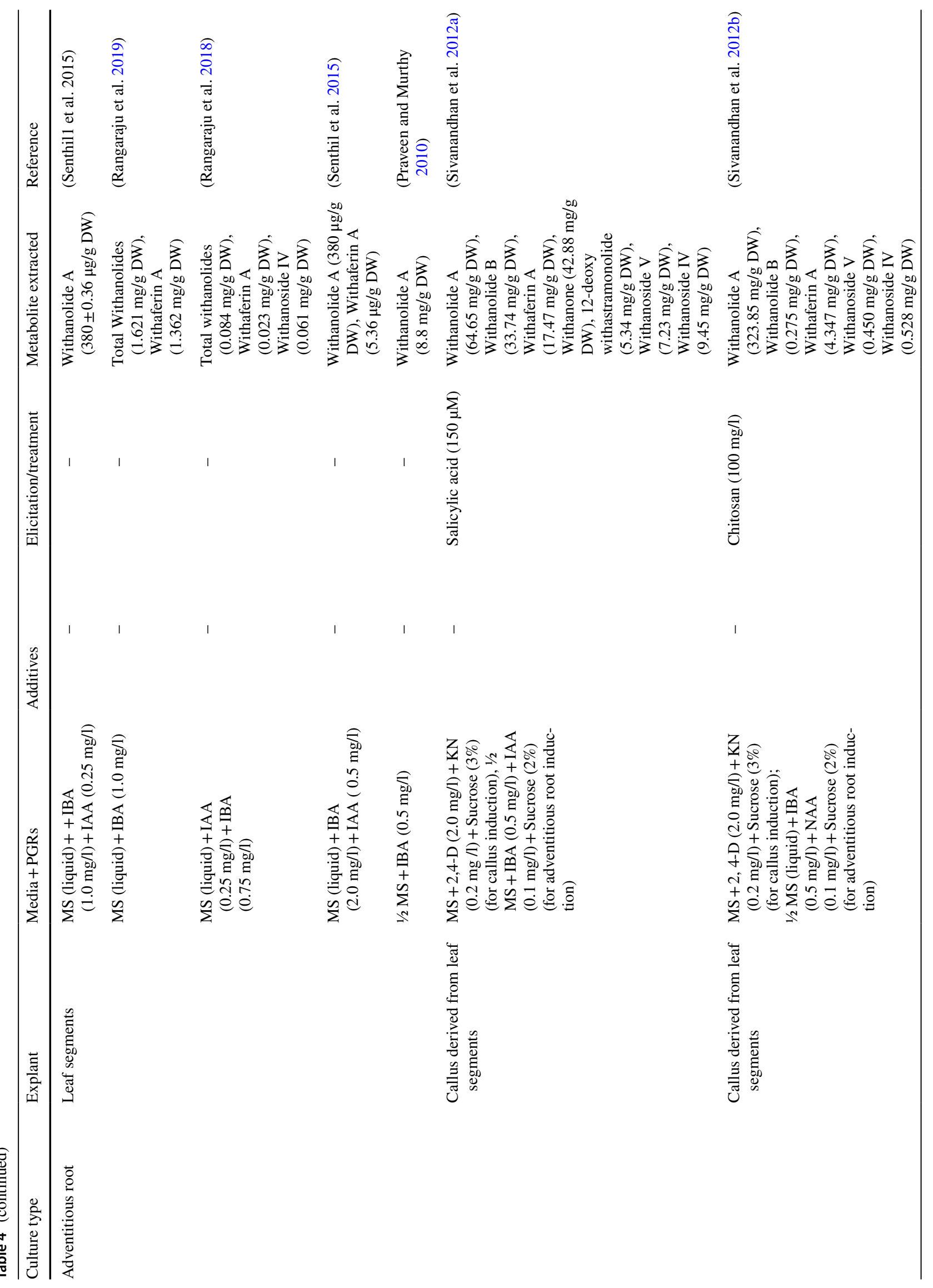




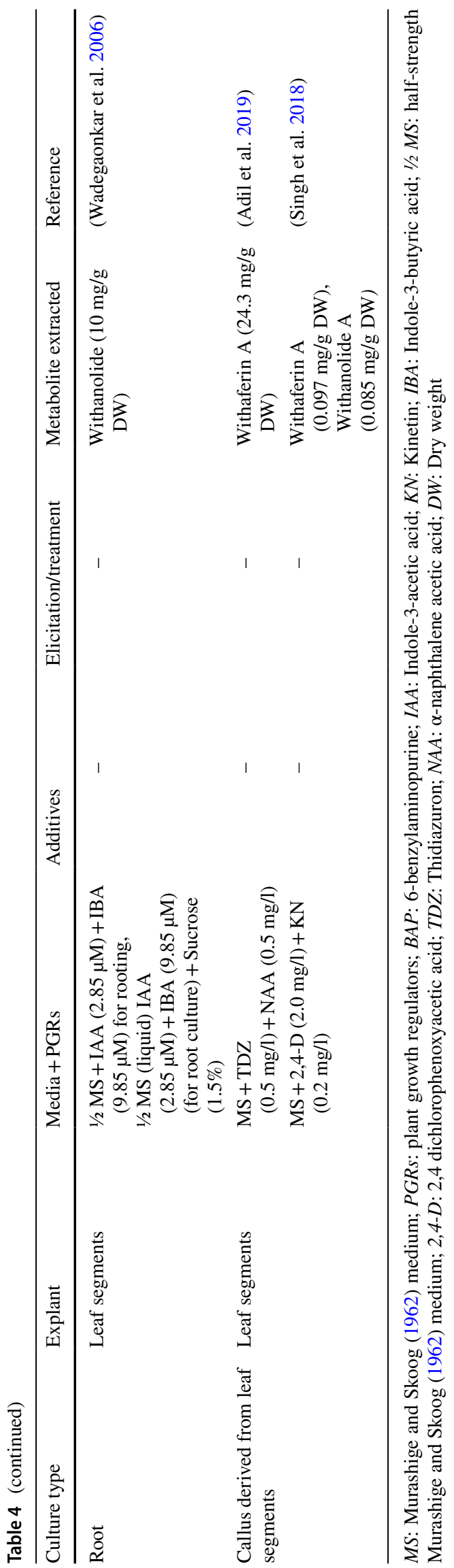

Media

The extraction of secondary metabolites on a large-scale is possible by manipulating the culture medium (Praveen and Murthy 2010). The ideal culture media should be inexpensive, readily available, easily prepared, and metabolite inducer for secondary metabolites production (VanderMolen et al. 2013). W. somnifera was studied for its accomplishments in the synthesis of withanolides under the influence of a basal media (Praveen and Murthy 2010; Ray and Jha 2001). The maximum content of withaferin $A(0.09 \%)$ was recorded in shoot tips proliferating on B5 medium in comparison with the other types of basal medium (MS, B5, WPM, and SH) (Ray and Jha 2001). Whereas, withanolide A accumulation was higher on MS medium $(0.065 \%)$ than in B5 medium (0.03\%). Similarly, the effect of different types of tissue culture medium (MS, B5, NN, and N6) on the production of withanolides from adventitious root cultures of W. somnifera was investigated (Praveen and Murthy 2010). Among the different media, the maximum accumulation of withanolide A was reported on MS medium ( $8.27 \mathrm{mg} / \mathrm{g} \mathrm{DW})$ followed by B5 Medium (6.66 mg/g DW). Furthermore, different strengths $(0.25,0.5,0.75,1.0,1.5$, 2.0) of MS medium were investigated to find the optimum nutrient content for the production of withanolide A and $1 / 2$ MS favoured the higher production of withanolide $\mathrm{A}$ in $W$. somnifera $(8.65 \mathrm{mg} / \mathrm{g} \mathrm{DW})$.

\section{Growth regulators}

The types and concentrations of PGRs particularly cytokinins affect the synthesis of withanolides in in vitro grown plants of W. somnifera (Roja et al. 1991). It was investigated the addition of different cytokinins (BA, Zeatin, KN, 2iP, and TDZ) to the culture medium influence the production of withanolides in multiple shoot cultures of W. somnifera (Sivanandhan et al. 2013). Among the different PGRs tested, the maximum increase in withanolide A (6-fold), withanolide B (7.6-fold), withaferin A (1.12-fold), and withanone (1.16-fold) was recorded in nutrient medium fortified with BA (0.6 mg/l) in comparison with control. Similarly, Ray and Jha (2001) recorded the maximum accumulation of withanolide D and withaferin A from shoot tips in the culture medium with BAP $(1.0 \mathrm{mg} / \mathrm{l})$, and a decrease in the content of withanolides was observed with an increased concentration of BAP $(2.0 \mathrm{mg} / \mathrm{l}-5.0 \mathrm{mg} / \mathrm{l})$. Further, adventitious roots obtained from the leaf segments of $W$. somnifera on $1 / 2 \mathrm{MS}$ medium enriched with IAA $(0.25 \mathrm{mg} / \mathrm{l})$ and IBA $(0.75 \mathrm{mg} / \mathrm{l})$ accumulated withaferin A and withanoside IV (Rangaraju et al. 2018). Similarly, adventitious roots obtained from the callus of leaf segments cultured on MS medium containing IBA $(0.5 \mathrm{mg} / \mathrm{l})$ and IAA $(0.1 \mathrm{mg} / \mathrm{l})$ stimulated the higher accumulation of all withanolides (Sivanandhan et al. 2012a). 
Also, the increased accumulation of withaferin A was observed in callus obtained from leaf segments on culture medium enriched with TDZ $(0.5 \mathrm{mg} / \mathrm{l})$ and NAA $(0.5 \mathrm{mg} / \mathrm{l})$ (Adil et al. 2019).

\section{Carbon and nitrogen sources}

The addition of carbon and nitrogen sources in the nutrient medium is critical for phytochemical production (Nielsen et al. 2019). In W. somnifera. the influence of various types of carbon sources (glucose, sucrose, fructose, and maltose) and nitrogen sources (ammonium nitrate, adenine sulphate, potassium nitrate, sodium nitrate, and L-glutamine) was studied on the synthesis of secondary metabolites (Sivanandhan et al. 2015). They found that the optimized culture medium (MS + $1.5 \mathrm{mg} / 1 \mathrm{BA}+0.3 \mathrm{mg} / \mathrm{l} \mathrm{IAA}$ ) with $6 \%$ sucrose and $20 \mathrm{mg} / \mathrm{l} \mathrm{L}$-glutamine induced maximum withanolides content $(2.05 \mathrm{mg} / \mathrm{g}$ DW withaferin A, $0.75 \mathrm{mg} / \mathrm{g} \mathrm{DW}$ withanolide A, $1.08 \mathrm{mg} / \mathrm{g}$ DW withanolide B, and $1.74 \mathrm{mg} / \mathrm{g}$ DW withanone). In literature, it was evidenced that nitrogen compounds interact with carbon sources to regulate the expression of pathway genes involved in secondary metabolite production. Similarly, Ray and Jha (2001) noted the higher production of withanolide $\mathrm{D}$ in culture medium augmented with a higher concentration (4\%) of sucrose. Whereas the maximum content of withaferin A was recorded in a nutrient medium enriched with $8 \%$ sucrose.

\section{Status of the medium}

In recent years, the liquid culture system considered an attractive alternative to a solid medium for the production of important phytochemicals due to the reduction in production costs (Sivanandhan et al., 2013; Pati et al. 2011). The use of a liquid culture system has been documented by many researchers in W. somnifera (Mir et al. 2014; Sivanandhan et al. 2013, 2014; Ray and Jha 2001; Senthil et al. 2015; Rangaraju et al. 2019, 2018). Mir et al. (2014) recorded the enhancement in withaferin A content in shoot cultures grown on $1 / 2$ MS liquid medium with BAP $(5.0 \mu \mathrm{M})$ after 5 weeks culture. Similarly, a higher accumulation of withanolides was recorded on MS liquid medium containing different PGRs and additives (Sivanandhan et al. 2013, 2014; Ray and Jha 2001).

\section{Additives}

The effect of growth additives such as coconut milk, yeast extract, casein hydrolysate, and spermidine on withanolides production was documented in W. somnifera (Ray and Jha 1991; Sivanandhan et al. 2013). Ray and Jha (1991) investigated the effect of different growth additives such as yeast extract, casein hydrolysate, and coconut milk on withanolides content. They found that the maximum accumulation of withaferin A (136 mg/100 g DW) on optimized MS liquid medium supplemented with coconut milk (10\%) after 4 weeks of shoot culture, while the higher content of withanolide D $(100 \mathrm{mg} / 100 \mathrm{~g} \mathrm{DW})$ was recorded in casein hydrolase $(500 \mathrm{mg} / \mathrm{l})$. Earlier research demonstrated that polyamines and PGRs imitate secondary metabolite production by activating particular genes in root and shoot cultures. Sivanandhan et al. (2013) found the increased production of withanolides in in vitro grown plants inoculated on a culture medium with PGRs and spermidine $(20 \mathrm{mg} / \mathrm{l})$.

\section{Elicitors}

Elicitation is a technique of inducing or increasing the production of secondary metabolites in plant tissue culture. The influence of different abiotic (salicylic acid, aluminum chloride, and methyl jasmonate) and biotic (chitosan) was investigated on the accumulation of withanolides in W. somnifera (Sivanandhan et al. 2012a, 2012b). They found a 48, 37, 29, and 20-fold enhancement of withanolide A, withanone, withanolide $\mathrm{B}$, and withaferin $\mathrm{A}$, respectively on elicitation of adventitious root culture with salicylic acid at the concentration of $150 \mu \mathrm{M}$ at 10 days exposure time. Further, the enhanced production of withanolides (1.14 to 1.18 -fold) was achieved on MS liquid medium enriched with $0.6 \mathrm{mg} / \mathrm{l}$ BA and $20 \mathrm{mg} / \mathrm{l}$ spermidine with a favourable response to elicitation with salicylic acid $(100 \mu \mathrm{M})$ at $4 \mathrm{~h}$ exposure time (Sivanandhan et al. 2013). Moreover, Sivanandhan and the group investigated the effect of seaweed extracts of Gracilaria edulis and Sargassum wightii on withanolides production in multiple shoot suspension culture of W. somnifera. The maximum content of withanolide $\mathrm{B}$, withaferin $\mathrm{A}$, and withanone was recorded at $24 \mathrm{~h}$ exposure time in MS liquid medium augmented with G. edulis (40\%) extract (Sivanandhan et al. 2014).

\section{Conclusion}

Due to a major worldwide trend toward phytotherapeutics, there has been a significant increase in the use of medicinal plants for the healthcare industry. Among medicinal plants, $W$. somnifera has gained a lot of interest owing to its enormous pharmacological properties against a large number of diseases. Hence, there is a need for the establishment of economical and feasible strategies for the large-scale propagation of W. somnifera. Plant cell and tissue culture have the potential to enable the rapid multiplication of elite cultivars of $W$. somnifera and help the herbal industries to have easy access to raw materials. The use of in vitro grown W. somnifera plants for the synthesis of pharmaceutically important constituents offers an alternative source for preclinical 
and clinical research. Hence, catalyzing the existing genetic resources through in vitro culture approaches will immensely help in understanding the biosynthesis, transport, accumulation, and modulation of secondary metabolites and will lead to further improvement of this hugely important medicinal plant.

Acknowledgements This work was supported by the Council of Scientific and Industrial Research (CSIR), Government of India, New Delhi, and Centre for Agricultural Research and Innovation (CARI) under the Rashtriya Uchchattar Shiksha Abhiyan (RUSA-II), GNDU, Amritsar. KK is thankful to UGC for Maulana Azad National Fellowship (F1-17.1/2017-18/MANF-2017-18-PUN-78763). SB is thankful for the fellowship received under Dr. D. S. Kothari Post-Doctoral fellowship (DSKPDF) scheme by UGC [(Grant No. F.4-2/2006 (BSR)/20-21/0380)].

Author contributions PKP conception of the review; KK, DD and SB surveyed the literature; KK drafted the manuscript; PKP and KK scrutinized and corrected the manuscript to its final version. All the authors read and approved the final version of the manuscript before its submission.

\section{Declarations}

Conflict of interest The authors declare that they have no conflict of interest.

\section{References}

Adil M, Abbasi BH, ul Haq I, (2019) Red light controlled callus morphogenetic patterns and secondary metabolites production in Withania somnifera L. Biotechnol Rep 24:e00380. https://doi. org/10.1016/j.btre.2019.e00380

Ahmad N, Anis M (2011) An efficient in vitro process for recurrent production of cloned plants of Vitex negundo L. Eur J Forest Res 130(2):135-144. https://doi.org/10.1007/s10342-010-0415-y

Arumugam A, Gopinath K (2013) In vitro regeneration of an endangered medicinal plant Withania somnifera using four different explants. Plant Tissue Cult Biotech 23(1):79-85

Autade RH, Fargade SA, Savant AR, Gangurde SS, Choudhary RS, Dighe SS (2016) Micropropagation of Ashwagandha (Withania somnifera). Biosci Biotech Res Comm 9:88-93

Behera S, Kar SK, Rout KK, Barik DP, Panda PC, Naik SK (2019) Assessment of genetic and biochemical fidelity of field-established Hedychium coronarium J. Koenig regenerated from axenic cotyledonary node on meta-topolin supplemented medium. Ind Crops Prod 134:206-215. https://doi.org/10.1016/j.indcrop.2019. 03.051

Behera S, Monalisa K, Meher RK, Mohapatra S, Madkami SK, Das PK, Naik PK \& Naik SK (2022) Phytochemical fidelity and therapeutic activity of micropropagated Curcuma amada Roxb.: A valuable medicinal herb. Ind Crops Prod 176:114401. https:// doi.org/10.1016/j.indcrop.2021.114401

Benson EE (2000) Sepecial symposium: In vitro plant recalcitrance in vitro plant recalcitrance: an introduction. In Vitro Cell Dev Biol Plant 36(3):141-148. https://doi.org/10.1007/ s11627-000-0029-z

Bhatia A, Bharti SK, Tewari SK, Sidhu OP, Roy R (2013) Metabolic profiling for studying chemotype variations in Withania somnifera (L.) Dunal fruits using GC-MS and NMR spectroscopy.
Phytochemistry 93:105-115. https://doi.org/10.1016/j.phyto chem.2013.03.013

Bomzan DP, Shilpashree H, Anjali P, Kumar SR \& Nagegowda DA (2020) Virus-induced gene silencing for functional genomics in Withania somnifera, an important indian medicinal plant Virus-Induced Gene Silencing in Plants. Springer, pp 139-154

Chakraborty N, Banerjee D, Ghosh M, Pradhan P, Gupta NS, Acharya K, Banerjee M (2013) Influence of plant growth regulators on callus mediated regeneration and secondary metabolites synthesis in Withania somnifera (L.) Dunal. Physiol Mol Biol Plants 19(1):117-125. https://doi.org/10.1007/ s12298-012-0146-2

Chandra P, Sharma V (2019) Marketing information system and strategies for sustainable and competitive medicinal and aromatic plants trade. Inf Dev 35(5):806-818. https://doi.org/10. 1177/0266666918802415

Chauhan RD, Taylor NJ (2018) Meta-topolin stimulates de novo shoot organogenesis and plant regeneration in cassava. Plant Cell Tiss Organ Cult (PCTOC) 132(1):219-224. https://doi. org/10.1007/s11240-017-1315-3

Chaurasiya ND, Sangwan NS, Sabir F, Misra L, Sangwan RS (2012) Withanolide biosynthesis recruits both mevalonate and DOXP pathways of isoprenogenesis in Ashwagandha Withania somnifera L.(Dunal). Plant Cell Rep 31(10):1889-1897. https:// doi.org/10.1007/s00299-012-1302-4

da Silva JAT, Hossain MM, Sharma M, Dobránszki J, Cardoso JC, Songjun Z (2017) Acclimatization of in vitro-derived Dendrobium. Hortic Plant J 3(3):110-124. https://doi.org/10.1016/j. hpj.2017.07.009

Dar RA, Shahnawaz M, Qazi PH (2017) General overview of medicinal plants: a review. J Phytopharm 6(6):349-351

De Silva M \& Senarath W (2009) In vitro mass propagation and greenhouse establishment of Withania somnifera (L.) Dunal (Solanaceae) and comparison of growth and chemical compounds of tissue cultured and seed raised plants. J Natl Sci Found 37(4)

Deka A, Kalita M, Baruah A (1999) In vitro micropropagation of potent herbal medicinal plant Withania somnifera (Ashwagandha). Environ Ecol 17(3):594-596

Dewir YH, Chakrabarty D, Lee S-H, Hahn E-J, Paek K-Y (2010) Indirect regeneration of Withania somnifera and comparative analysis of withanolides in in vitro and greenhouse grown plants. Biol Plant 54(2):357-360. https://doi.org/10.1007/ s10535-010-0063-6

Dhanjal JK, Kumar V, Garg S, Subramani C, Agarwal S, Wang J, Zhang H, Kaul A, Kalra RS, Kaul SC (2021) Molecular mechanism of anti-SARS-CoV2 activity of Ashwagandha-derived withanolides. Int J Biol Macromol. https://doi.org/10.1016/j. ijbiomac.2021.06.015

Fatima N, Anis M (2011) Thidiazuron induced high frequency axillary shoot multiplication in Withania somnifera L. Dunal J Med Plant Res 5(30):6681-6687. https://doi.org/10.5897/JMPR11.622

Fatima N, Anis M (2012) Role of growth regulators on in vitro regeneration and histological analysis in Indian ginseng (Withania somnifera L.) Dunal. Physiol Mol Biol Plants 18(1):59-67. https:// doi.org/10.1007/s12298-011-0099-x

Fatima N, Ahmad N, Anis M (2011) Enhanced in vitro regeneration and change in photosynthetic pigments, biomass and proline content in Withania somnifera L.(Dunal) induced by copper and zinc ions. Plant Physiol Biochem 49(12):1465-1471. https://doi.org/ 10.1007/s12010-015-1732-x

Fatima N, Ahmad N, Ahmad I, Anis M (2015) Interactive effects of growth regulators, carbon sources, $\mathrm{pH}$ on plant regeneration and assessment of genetic fidelity using single primer amplification reaction (SPARS) techniques in Withania somnifera L. Appl Biochem Biotechnol 177(1):118-136 
Franklin G, Pius P, Ignacimuthu S (2000) Factors affecting in vitro flowering and fruiting of green pea (Pisum sativum L.). Euphytica 115(1):65-74 https://doi.org/10.1023/A:1003982900117

Furmanowa M, Gajdzis-Kuls D, Ruszkowska J, Czarnocki Z, Obidoska G, Sadowska A, Rani R, Upadhyay SN (2001) In vitro propagation of Withania somnifera and isolation of withanolides with immunosuppressive activity. Planta Med 67(02):146-149. https://doi.org/10.1055/s-2001-11494

Gamborg OLc, Miller RA \& Ojima K, (1968) Nutrient requirements of suspension cultures of soybean root cells. Exp Cell Res 50(1):151-158. https://doi.org/10.1016/0014-4827(68)90403-5

Gantait S, Das A, Mandal N (2015) Stevia: a comprehensive review on ethnopharmacological properties and in vitro regeneration. Sugar Tech 17(2):95-106. https://doi.org/10.1007/ s12355-014-0316-3

George EF, Hall MA, De Klerk G-J (2008) The components of plant tissue culture media II: organic additions, osmotic and $\mathrm{pH}$ effects, and support systems Plant propagation by tissue culture. Springer, p 115-173. https://doi.org/10.1007/978-1-4020-5005-3_4

Ghimire BK, Seong ES, Kim EH, Lamsal K, Yu CY, Chung IM (2010) Direct shoot organogenesis from petiole and leaf discs of Withania somnifera (L.) Dunal. Afr J Biotechnol 9(44):7453-7461. https://doi.org/10.5897/AJB10.1250

Gonçalves S, Romano A (2018) Production of plant secondary metabolites by using biotechnological tools. Secondary metabolites, sources and applications, IntechOpen:81-99

Govindaraju B, Rao SR, Venugopal R, Kiran S, Kaviraj C, Rao S (2003) High frequency plant regeneration in Ashwagandha (Withania somnifera (L.) Dunal): an important medicinal plant. Plant Cell Biotechnol Mol Biol 4(1-2):49-56

Gupta V, Guleri R, Gupta M, Kaur N, Kaur K, Kumar P, Anand M, Kaur G, Pati PK (2020). Anti-neuroinflammatory potential of Tylophora indica (Burm. f) Merrill and development of an efficient in vitro propagation system for its clinical use. PLoS One 15, e0230142. https://doi.org/10.1371/journal.pone.0230142

Halder T, Ghosh B (2021) Cytological, genetical and phytochemically stable meta-Topolin (mT)-induced mass propagation of underutilized. Physalis minima L. for production of withaferin A. Biocatal Agric Biotechnol 33:102012. https://doi.org/10.1016/j. bcab.2021.102012

Isah T, Umar S, Mujib A, Sharma MP, Rajasekharan P, Zafar N, Frukh A (2018) Secondary metabolism of pharmaceuticals in the plant in vitro cultures: strategies, approaches, and limitations to achieving higher yield. Plant Cell Tiss Organ Cult (PCTOC) 132(2):239-265. https://doi.org/10.1007/s11240-017-1332-2

Jamshidi-Kia F, Lorigooini Z, Amini-Khoei H (2018) Medicinal plants: Past history and future perspective. J Herbmed Pharmacol 7(1). https://doi.org/10.15171/jhp.2018.01

Joshi AG, Padhya MA (2010) Shoot regeneration from leaf explants of Withania somnifera (L.) Dunal. Not Sci Biol 2(1):63-65. https:// doi.org/10.15835/nsb213609

Kannan T, Anbazhakan S (2016) Direct regeneration of Withania somnifera (L.) Dunal-A medicinal plant. World Scientific News 32:73-83

Karthikeyan G, Swamy MK, RajhaViknesh M, Shurya R \& Sudhakar N (2019) Scientific validation of the usefulness of Withania somnifera Dunal. in the prevention of diseases. Medicinal plants: chemistry, pharmacology, and therapeutic applications. CRC Press, Boca Raton:175-188

Kaur A, Kumar A (2020) The effect of gelling agent, medium pH and silver nitrate on adventitious shoot regeneration in Solanum tuberosum. bioRxiv https://doi.org/10.1101/2020.01.03.894063

Kaur K, Singh P, Guleri R, Singh B, Kaur K, Singh V \& Pati PK (2017) Biotechnological approaches in propagation and improvement of Withania somnifera (L.) Dunal Science of Ashwagandha:
Preventive and Therapeutic Potentials. Springer, p 459-478 https://doi.org/10.1007/978-3-319-59192-6_22

Kaur K, Kaur K, Bhandawat A, Pati PK (2021a) In vitro shoot multiplication using meta-Topolin and leaf-based regeneration of a withaferin A rich accession of Withania somnifera (L.) Dunal. Ind Crops Prod 171:113872. https://doi.org/10.1016/j.indcrop. 2021.113872

Kaur K, Singh P, Kaur K, Bhandawat A, Nogia P, Pati PK (2021b) Development of robust in vitro culture protocol for the propagation of genetically and phytochemically stable plants of Withania somnifera (L.) Dunal (Ashwagandha). Ind Crops Prod 166:113428. https://doi.org/10.1016/j.indcrop.2021.113428

Kucharska D, Orlikowska T, Maciorowski R, Kunka M, Wójcik D, Pluta S (2020) Application of meta-topolin for improving micropropagation of gooseberry (Ribes grossularia). Sci Hortic 272:109529. https://doi.org/10.1016/j.scienta.2020.109529

Kulkarni S, Dhir A (2008) Withania somnifera: an Indian ginseng. Prog Neuropsychopharmacol Biol Psychiatry 32(5):1093-1105. https://doi.org/10.1016/j.pnpbp.2007.09.011

Kulkarni AA, Thengane S, Krishnamurthy K (1996) Direct in vitro regeneration of leaf explants of Withania somnifera (L.) Dunal. Plant Sci 119(1-2):163-168

Kulkarni AA, Thengane S, Krishnamurthy K (2000) Direct shoot regeneration from node, internode, hypocotyl and embryo explants of Withania somnifera. Plant Cell Tiss Organ Cult 62(3):203-209. https://doi.org/10.1016/0168-9452(96)04462-7

Kumar A, Kaul M, Bhan M, Khanna PK, Suri K (2007) Morphological and chemical variation in 25 collections of the Indian medicinal plant, Withania somnifera (L.) Dunal (Solanaceae). Genet Resour Crop Evol 54(3):655-660. https://doi.org/10.1007/ s10722-006-9129-x

Kumar OA, Jyothirmayee G, Tata SS (2011) In vitro plant regeneration from leaf explants of Withania somnifera (L) Dunal (Ashwaganda)-an important medicinal plant. Res Biotechnol 2(5)

Lal R (2015) Quantification of adaptability and stability among genotypes/cultivars for root yield in Ashwagandha (Withania somnifera L.). Ind Crops Prod 77:648-657. https://doi.org/10.1016/j. indcrop.2015.09.035

Lloyd G, McCown B (1980) Commercially-feasible micropropagation of mountain laurel, Kalmia latifolia, by use of shoot-tip culture. Commercially-Feasible Micropropagation of Mountain Laurel, Kalmia Latifolia, by Use of Shoot-Tip Culture 30:421-427

Logesh P, Settu A, Thangavel K, Ganapathi A (2010) Direct in vitro regeneration of Withania somnifera (L.) Dunal through leaf disc culture. Int J Biol Technol 1:1-4

Lozzi A, Abdelwahd R, Mentag R, Abousalim A (2019) Development of a new culture medium and efficient protocol for in vitro micropropagation of Ceratonia siliqua L. In Vitro Cell Dev Biol Plant 55(5):615-624. https://doi.org/10.1007/s11627-019-09990-6

Malik S, Sharma M, Ahuja PS (2016) An efficient and economic method for in vitro propagation of Arnebia euchroma using liquid culture system. Am J Biotechnol Med Res 1(1):19-25

Mallubhotla S, Ahuja A, Kumar A, Sharma R, Verma V, Suri K \& Vij $S$ Field performance, RAPD analysis and withanolide profiling of micropropagated plants of WSR-an elite cultivar of Indian Ginseng (Withania somnifera L. Dunal). In: IV International Symposium on Acclimatization and Establishment of Micropropagated Plants 865, 2008. p 199-207 https://doi.org/10.17660/ ActaHortic.2010.865.25

Manickam V, Mathavan RE, Antonisamy R (2000) Regeneration of Indian ginseng plantlets from stem callus. Plant Cell Tiss Organ Cult 62(3):181-185. https://doi.org/10.1023/A:1006499522799

Meher SK, Das B, Panda P, Bhuyan G, Rao M (2016) Uses of Withania somnifera (Linn) Dunal (Ashwagandha) in Ayurveda and its pharmacological evidences. Res J Pharmacol Pharmacodyn 8(1):23. https://doi.org/10.5958/2321-5836.2016.00006.9 
Mir BA, Koul S, Kuar A, Sharma S, Kaul MK, Soodan AS (2012) Reproductive behaviour and breeding system of wild and cultivated types of Withania somnifera (L.) Dunal. J Med Plant Res 6(5):754-762. https://doi.org/10.5897/JMPR11.1303

Mir BA, Khazir J, Hakeem KR, Koul S, Cowan DA (2014) Enhanced production of withaferin-A in shoot cultures of Withania somnifera (L) Dunal. J Plant Biochem Biotechnol 23(4):430-434. https://doi.org/10.1007/s13562-014-0264-8

Mishra BS, Singh M, Aggrawal P, Laxmi A (2009) Glucose and auxin signaling interaction in controlling Arabidopsis thaliana seedlings root growth and development. PLoS ONE 4(2):e4502. https://doi.org/10.1371/journal.pone.0004502

Mohammadi E, Bagheri K, Beigmohammadi M, Sharafi A (2020) In vitro direct organogenesis and genetically transformed root cultures in Artemisia sieberi Besser as a source of pharmaceutical compound artemisinin. J BioSci Biotechnol 9(2):37-45

Murashige T, Skoog F (1962) A revised medium for rapid growth and bio assays with tobacco tissue cultures. Physiol Plant 15(3):473497. https://doi.org/10.1111/j.1399-3054.1962.tb08052.x

Naaz A, Hussain S, Anis M, Alatar A (2019) Meta-topolin improved micropropagation in Syzygium cumini and acclimatization to ex vitro conditions. Biol Plant 63(1):174-182. https://doi.org/10. 32615/bp.2019.020

Namdeo AG, Sharma A, Yadav KN, Gawande R, Mahadik KR, LopezGresa MP, Kim HK, Choi YH, Verpoorte R (2011) Metabolic characterization of Withania somnifera from different regions of India using NMR spectroscopy. Planta Med 77:1958-1964. https://doi.org/10.1055/s-0031-1279997

Namdeo AG, Ingawale DK (2020) Ashwagandha: Advances in plant biotechnological approaches for propagation and production of bioactive compounds. J Ethnopharmacol 113709. https://doi.org/ 10.1016/j.jep.2020.113709

Nayak S, Kumar S, Satapathy K, Moharana A, Behera B, Barik D, Acharya L, Mohapatra P, Jena P, Naik S (2013) In vitro plant regeneration from cotyledonary nodes of Withania somnifera $(\mathrm{L}$.) Dunal and assessment of clonal fidelity using RAPD and ISSR markers. Acta Physiol Plant 35(1):195-203. https://doi.org/10. 1007/s11738-012-1063-2

Nielsen E, Temporiti MEE, Cella R (2019) Improvement of phytochemical production by plant cells and organ culture and by genetic engineering. Plant Cell Rep 38(10):1199-1215. https:// doi.org/10.1007/s00299-019-02415-z

Nitsch J, Nitsch C (1969) Haploid plants from pollen grains. Science 163(3862):85-87. https://doi.org/10.1126/science.163.3862.85

Pandey V, Misra P, Chaturvedi P, Mishra MK, Trivedi PK, Tuli R (2010) Agrobacterium tumefaciens-mediated transformation of Withania somnifera (L.) Dunal: an important medicinal plant. Plant Cell Rep 29(2):133-141. https://doi.org/10.1007/ s00299-009-0805-0

Pati PK, Rath SP, Sharma M, Sood A, Ahuja PS (2006) In vitro propagation of rose-a review. Biotechnol Adv 24(1):94-114. https:// doi.org/10.1016/j.biotechadv.2005.07.001

Pati PK, Kaur J, Singh P (2011) A liquid culture system for shoot proliferation and analysis of pharmaceutically active constituents of Catharanthus roseus (L.) G. Don. Plant Cell Tiss Organ Cult (PCTOC) 105(3):299-307. https://doi.org/10.1007/ s11240-010-9868-4

Perveen S, Varshney A, Anis M, Aref IM (2011) Influence of cytokinins, basal media and $\mathrm{pH}$ on adventitious shoot regeneration from excised root cultures of Albizia lebbeck. J For Res 22(1):4752. https://doi.org/10.1007/s11676-011-0124-5

Praveen N, Murthy H (2010) Production of withanolide-A from adventitious root cultures of Withania somnifera. Acta Physiol Plant 32(5):1017-1022. https://doi.org/10.1007/s11738-010-0489-7
Puchooa D, Purseramen P, Rujbally B (1999) Effects of medium support and gelling agent in the tissue culture of tobacco (Nicotiana tabacum). University of Mauritius Res J 3:129-144

Purohit SD, Teixeira da Silva J, Habibi N (2011) Current approaches for cheaper and better micropropagation technologies. Int J Plant Dev Biol 5:1-36

Rangaraju S, Lokesha A, Aswath CR (2018) Standardization of various factors for production of adventitious roots in selected varieties of Withania somnifera and estimation of total withanolides by High Performance Liquid Chromatography. Biosci Biotechnol Res Commun 11(3):451-460

Rangaraju S, Lokesha A, Aswath CR (2019) Improved production of withanolides in adventitious root cultures of Withania somnifera by suspension culture method. Biosci Biotech Res Comm 12 (1):73-79. https://doi.org/10.21786/bbrc/12.1/10

Rani G, Grover I (1999) In vitro callus induction and regeneration studies in Withania somnifera. Plant Cell Tiss Organ Cult 57(1):2327. https://doi.org/10.1023/A:1006329532561

Rani A, Kumar M, Kumar S (2016) Effect of phytohormones on shoot apex and leaf explants of Withania somnifera (Ashwagandha). J Appl Natl Sci 8(1):412-415. https://doi.org/10.31018/jans.v8i1. 808

Rathore NS, Rathore N, Shekhawat N (2013) In vitro flowering and seed production in regenerated shoots of Cleome viscosa. Ind Crops Prod 50:232-236. https://doi.org/10.1016/j.indcrop.2013. 07.032

Ray S, Jha S (2001) Production of withaferin A in shoot cultures of Withania somnifera. Planta Med 67(05):432-436. https://doi.org/ 10.1055/s-2001-15811

Roja G, Heble M, Sipahimalani A (1991) Tissue cultures of Withania somnifera: morphogenesis and withanolide synthesis. Phytother Res 5(4):185-187. https://doi.org/10.1002/ptr.2650050411

Rout JR, Sahoo SL, Das R (2011) An attempt to conserve Withania somnifera (L.) Dunal-A highly essential medicinal plant, through in vitro callus culture. Pak J Bot 43:1837-1842

Sabir F, Sangwan NS, Chaurasiya ND, Misra LN, Tuli R, Sangwan RS (2008) Rapid micropropagation of Withania somnifera L. accessions from axillary meristems. J Herbs Spices Med Plants 13(4):123-133. https://doi.org/10.1080/10496470801946166

Sabir F, Mishra S, Sangwan RS, Jadaun JS, Sangwan NS (2013) Qualitative and quantitative variations in withanolides and expression of some pathway genes during different stages of morphogenesis in Withania somnifera Dunal. Protoplasma 250(2):539-549. https://doi.org/10.1007/s00709-012-0438-y

Saema S, Ahmad IZ, Misra P (2015) Rapid in vitro plant regeneration from nodal explants of Withania somnifera (L.) Dunal: a valuable medicinal plant. Int J Sci Res 4:1649-1652

Sangeetha P, Venkatachalam P (2014) Induction of direct shoot organogenesis and in vitro flowering from shoot tip explants of cucumber (Cucumis sativus L. cv. 'Green long'). In Vitro Cell Dev Biol Plant 50(2):242-248. https://doi.org/10.1007/s11627-013-9571-3

Sangwan RS, Chaurasiya ND, Lal P, Misra L, Tuli R, Sangwan NS (2008) Withanolide A is inherently de novo biosynthesized in roots of the medicinal plant Ashwagandha (Withania somnifera). Physiol Plant 133(2):278-287. https://doi.org/10.1111/j.13993054.2008.01076.x

Sangwan NS \& Sangwan RS (2014) Secondary metabolites of traditional medical plants: a case study of Ashwagandha (Withania somnifera) Applied plant cell biology. Springer, p 325-367 https://doi.org/10.1007/978-3-642-41787-0_11

Saritha K, Naidu C (2007) In vitro flowering of Withania somnifera Dunal.-an important antitumor medicinal plant. Plant Sci 172(4):847-851. https://doi.org/10.1016/j.plantsci.2006.12.016

Schenk RU, Hildebrandt A (1972) Medium and techniques for induction and growth of monocotyledonous and dicotyledonous plant 
cell cultures. Can J Bot 50(1):199-204. https://doi.org/10.1139/ b72-026

Sen J, Sharma A (1991) Micropropagation of Withania somnifera from germinating seeds and shoot tips. Plant Cell Tiss Organ Cult 26(2):71-73. https://doi.org/10.1007/BF00036108

Senthil K, Thirugnanasambantham P, Oh TJ, Kim SH, Choi HK (2015) Free radical scavenging activity and comparative metabolic profiling of in vitro cultured and field grown Withania somnifera roots. PLoS ONE 10(4):e0123360. https://doi.org/10.1371/journ al.pone. 0123360

Sharada M, Ahuja A, Suri K, Vij S, Khajuria R, Verma V, Kumar A (2007) Withanolide production by in vitro cultures of Withania somnifera and its association with differentiation. Biol Plant 51(1):161-164. https://doi.org/10.1007/s10535-007-0031-y

Sharma S, Sharma MC, Kohli D (2009) In vitro micro propagation of medicinally important roots and axillary bud combination. J Optoelectron Biomed Mater 4:379-381

Sharma N, Sachdeva P, Dhiman M, Koshy EP (2015) Comparative evaluation of in vitro regeneration potential of seeds of $W$. somnifera and $W$. coagulans. Biotechnol Int 8(1):21-33

Shasmita, Rai M, Naik SK (2018) Exploring plant tissue culture in Withania somnifera (L.) Dunal: In vitro propagation and secondary metabolite production. Crit Rev Biotechnol 38(6):836-850. https://doi.org/10.1080/07388551.2017.1416453

Shekhawat MS, Priyadharshini S, Jogam P, Kumar V, Manokari M (2021) Meta-topolin and liquid medium enhanced in vitro regeneration in Scaevola taccada (Gaertn.) Roxb. In Vitro Cell Dev Biol Plant 1-11. https://doi.org/10.1007/s11627-020-10156-y

Shukla DD, Bhattarai N, Pant B (2010) In-vitro mass propagation of Withania somnifera (L.) Dunal. Nepal Journal of Science and Technology 11:101-106. https://doi.org/10.3126/njst.v11i0.4131

Singh A (2018) Efficient micropropagation protocol for Jatropha curcas using liquid culture medium. J Crop Sci Biotechnol 21(1):89-94. https://doi.org/10.1007/s12892-017-0004-0

Singh P, Guleri R, Singh V, Kaur G, Kataria H, Singh B, Kaur G, Kaul SC, Wadhwa R, Pati PK (2015) Biotechnological interventions in Withania somnifera (L.) Dunal. Biotechnol Genet Eng Rev 31(1-2):1-20. https://doi.org/10.1080/02648725.2015.1020467

Singh P, Guleri R, Angurala A, Kaur K, Kaur K, Kaul SC, Wadhwa R, Pati PK (2017) Addressing challenges to enhance the bioactives of Withania somnifera through organ, tissue, and cell culture based approaches. Biomed Res Int. https://doi.org/10.1155/2017/ 3278494

Singh M, Shah P, Punetha H, Agrawal S (2018) Varietal comparison of withanolide contents in different tissues of Withania somnifera (L.) Dunal (Ashwagandha). Int J Life Sci Sci Res 4(3):17521758. https://doi.org/10.21276/ijlssr.2018.4.3.3

Sivanandhan G, Mariashibu TS, Arun M, Rajesh M, Kasthurirengan S, Selvaraj N, Ganapathi A (2011) The effect of polyamines on the efficiency of multiplication and rooting of Withania somnifera (L.) Dunal and content of some withanolides in obtained plants. Acta Physiol Plant 33(6):2279. https://doi.org/10.1007/ s11738-011-0768-y

Sivanandhan G, Arun M, Mayavan S, Rajesh M, Jeyaraj M, Dev GK, Manickavasagam M, Selvaraj N, Ganapathi A (2012a) Optimization of elicitation conditions with methyl jasmonate and salicylic acid to improve the productivity of withanolides in the adventitious root culture of Withania somnifera (L.) Dunal. Appl Biochem Biotechnol 168(3):681-696. https://doi.org/10.1007/ s12010-012-9809-2

Sivanandhan G, Arun M, Mayavan S, Rajesh M, Mariashibu T, Manickavasagam M, Selvaraj N, Ganapathi A (2012b) Chitosan enhances withanolides production in adventitious root cultures of Withania somnifera (L.) Dunal. Ind Crops Prod 37(1):124-129. https://doi.org/10.1016/j.indcrop.2011.11.022
Sivanandhan G, Rajesh M, Arun M, Jeyaraj M, Dev GK, Arjunan A, Manickavasagam M, Muthuselvam M, Selvaraj N, Ganapathi A (2013) Effect of culture conditions, cytokinins, methyl jasmonate and salicylic acid on the biomass accumulation and production of withanolides in multiple shoot culture of Withania somnifera (L.) Dunal using liquid culture. Acta Physiol Plant 35(3):715-728. https://doi.org/10.1007/s11738-012-1112-x

Sivanandhan G, Selvaraj N, Ganapathi A, Manickavasagam M (2014) Improved production of withanolides in shoot suspension culture of Withania somnifera (L.) Dunal by seaweed extracts. Plant Cell Tiss Organ Cult (PCTOC) 119(1):221-225. https://doi.org/10. 1007/s11240-014-0521-5

Sivanandhan G, Selvaraj N, Ganapathi A, Manickavasagam M (2015) Effect of nitrogen and carbon sources on in vitro shoot multiplication, root induction and withanolides content in Withania somnifera (L.) Dunal. Acta physiol plant 37(2):1-10. https://doi. org/10.1007/s11738-014-1758-7

Sivanandhan G, Selvaraj N, Ganapathi A, Lim YP (2020) Up-regulation of Squalene synthase in hairy root culture of Withania somnifera (L.) Dunal yields higher quantities of withanolides. Ind Crops Prod 154:112706. https://doi.org/10.1016/j.indcrop. 2020.112706

Sivanesan I (2007) Direct regeneration from apical bud explants of Withania somnifera Dunal. Indian J Biotechnol 6:125-127. http://nopr.niscair.res.in/handle/123456789/5023

Sivanesan I, Murugesan K (2008) An efficient regeneration from nodal explants of Withania somnifera Dunal. Asian J Plant Sci 7(6):551-556

Sivanesan I, Park SW (2015) Optimizing factors affecting adventitious shoot regeneration, in vitro flowering and fruiting of Withania somnifera (L.) Dunal. Ind Crops Prod 76:323-328. https://doi. org/10.1016/j.indcrop.2015.05.014

Smetanska I (2008) Production of secondary metabolites using plant cell cultures. Food Biotechnol 187-228

Strnad M, Hanuš J, Vaněk T, Kamínek M, Ballantine JA, Fussell B, Hanke DE (1997) Meta-topolin, a highly active aromatic cytokinin from poplar leaves (Populus $\times$ canadensis Moench., cv. Robusta). Phytochemistry 45(2):213-218. https://doi.org/10. 1016/S0031-9422(96)00816-3

Supe U, Dhote F, Roymon M (2006) In vitro plant regeneration of Withania somnifera. Plant Tissue Cult Biotechnol 16(2):111-115

Udayakumar R, Choi C, Kim K, Kim S, Kasthurirengan S, Mariashibu T, JJ SR, Ganapathi A (2013) In vitro plant regeneration from epicotyl explant of Withania somnifera (L.) Dunal. J Med Plant Res 7(1):43-52. https://doi.org/10.5897/JMPR12.087

Udayakumar R, Ganapathi A, Kim SC, Choi CW (2014) Indirect regeneration of Withania somnifera from nodal explants. Biotechnol J Int:366-378. https://doi.org/10.9734/BBJ/2014/7511

Uritu CM, Mihai CT, Stanciu G-D, Dodi G, Alexa-Stratulat T, Luca A, Leon-Constantin M-M, Stefanescu R, Bild V, Melnic S (2018) Medicinal plants of the family Lamiaceae in pain therapy: a review. Pain Res Manage. https://doi.org/10.1155/2018/7801543

Vaidya B, Asanakunov B, Shahin L, Jernigan H, Joshee N, Dhekney SA (2019) Improving micropropagation of Mentha $\times$ piperita L. using a liquid culture system. In Vitro Cell Dev Biol Plant 55(1):71-80. https://doi.org/10.1007/s11627-018-09952-4

VanderMolen KM, Raja HA, El-Elimat T, Oberlies NH (2013) Evaluation of culture media for the production of secondary metabolites in a natural products screening program. AMB Express 3(1):1-7. https://doi.org/10.1186/2191-0855-3-71

Vega A, O’Brien JA, Gutiérrez RA (2019) Nitrate and hormonal signaling crosstalk for plant growth and development. Curr Opin Plant Biol 52:155-163. https://doi.org/10.1016/j.pbi.2019.10.001

Wadegaonkar P, Bhagwat K, Rai M (2006) Direct rhizogenesis and establishment of fast growing normal root organ culture of 
Withania somnifera Dunal. Plant Cell Tiss Organ Cult 84(2):223225. https://doi.org/10.1007/s11240-005-9011-0

Waman A, Sathyanarayana B, Umesha K, Gowda B, Ashok T, Rajesh A, Guruprakash R (2011) Optimization of growth regulators and explant source for micropropagation and cost effective ex vitro rooting in 'Poshita' Winter Cherry (Withania somnifera L.). J Appl Hort 11:150-153

Wangdi K, Sarethy IP (2016) Evaluation of micropropagation system of Bacopa monnieri L. in liquid culture and its effect on antioxidant properties. J Herbs Spices Med Plants 22(1):69-80. https://doi. org/10.1080/10496475.2015.1020404
Wen S-S, Chen L, Tian R-N (2020) Micropropagation of tree peony (Paeonia sect. Moutan): A review. Plant Cell Tiss Organ Cult (PCTOC) 141(1):1-14. https://doi.org/10.1007/ s11240-019-01747-8

Yildiz M (2012) The prerequisite of the success in plant tissue culture: high frequency shoot regeneration. Recent advances in plant in vitro culture. Intech, Rijeka:63-90

Publisher's Note Springer Nature remains neutral with regard to jurisdictional claims in published maps and institutional affiliations. 